\title{
Taxonomy and toxicity of Prorocentrum from Perhentian Islands (Malaysia), with a description of a non-toxigenic species Prorocentrum malayense sp. nov. (Dinophyceae)
}

\author{
Zhen Fei Lim ${ }^{\mathrm{a}}$, Zhaohe Luo ${ }^{\mathrm{b}}$, Li Keat Lee ${ }^{\mathrm{a}}$, Kieng Soon Hii ${ }^{\mathrm{a}}$, Sing Tung Teng ${ }^{\mathrm{c}}$, Leo Lai Chan ${ }^{\mathrm{d}}$, \\ Nicolas Chomérate ${ }^{\mathrm{e}}$, Bernd Krock ${ }^{\mathrm{f}}$, Haifeng Gu ${ }^{\mathrm{b}}$, Po Teen Lim ${ }^{\mathrm{a}}$, Chui Pin Leaw ${ }^{\mathrm{a}, *}$ \\ ${ }^{a}$ Bachok Marine Research Station, Institute of Ocean and Earth Sciences, University of Malaya, 16310 Bachok, Kelantan, Malaysia \\ ${ }^{\mathrm{b}}$ Third Institute of Oceanography, SOA, Xiamen, 361005, China \\ ${ }^{\mathrm{c}}$ Faculty of Resource Science and Technology, Universiti Malaysia Sarawak, 94300, Kota Samarahan, Sarawak, Malaysia \\ ${ }^{\mathrm{d}}$ State Key Laboratory in Marine Pollution, Department of Biomedical Sciences, City University of Hong Kong, Hong Kong, 999077, China \\ ${ }^{\mathrm{e}}$ IFREMER, Department ODE, Laboratory Environment and Resources Bretagne Occidentale, Station de Biologie Marine, Place de la Croix, 29900, Concarneau, France \\ ${ }^{\mathrm{f}}$ Alfred Wegener Institut-Helmholtz Zentrum für Polar- und Meeresforschung, Am Handelshafen 12, D-27570, Bremerhaven, Germany
}

\section{A R T I C L E I N F O}

\section{Keywords:}

Diarrhetic shellfish poisoning

ITS2 secondary structure

Morphology

Periflagellar area

Phylogeny

\begin{abstract}
A B S T R A C T
Thirteen isolates of Prorocentrum species were established from the coral reefs of Perhentian Islands Marine Park, Malaysia and underwent morphological observations and molecular characterization. Six species were found: $P$. caipirignum, $P$. concavum, $P$. cf. emarginatum, $P$. lima, $P$. mexicanum and a new morphotype, herein designated as $P$. malayense sp. nov. Prorocentrum malayense, a species closely related to $P$. leve, $P$. cf. foraminosum, $P$. sp. aff. foraminossum, and $P$. concavum (Clade A sensu Chomérat et al. 2018), is distinguished from its congeners as having larger thecal pore size and a more deeply excavated V-shaped periflagellar area. Platelet arrangement in the periflagellar area of $P$. malayense is unique, with the presence of platelet $1 \mathrm{a}$ and $1 \mathrm{~b}$, platelet 2 being the most anterior platelet, and a broad calabash-shaped platelet 3 . The species exhibits consistent genetic sequence divergences for the nuclear-encoded large subunit ribosomal RNA gene (LSU rDNA) and the second internal transcribed spacer (ITS2). The phylogenetic inferences further confirmed that it represents an independent lineage, closely related to species in Clade A sensu Chomérat et al. Pairwise comparison of ITS2 transcripts with its closest relatives revealed the presence of compensatory base changes (CBCs). Toxicity analysis showed detectable levels of okadaic acid in $P$. lima (1.0-1.6 pg cell $\left.{ }^{-1}\right)$ and $P$. caipirignum $\left(3.1 \mathrm{pg}\right.$ cell $\left.^{-1}\right)$; this is the first report of toxigenic $P$. caipirignum in the Southeast Asian region. Other Prorocentrum species tested, including the new species, however, were below the detection limit.
\end{abstract}

\section{Introduction}

The genus Prorocentrum Ehrenberg is a group of dinoflagellates that can be found in planktonic and benthic marine ecosystems (Faust, 1990; Chomérat et al., 2010; Hoppenrath et al., 2013), with 75 valid species hitherto (Guiry and Guiry, 2018), bisectioned into planktonic and benthic/epiphytic. At least ten species (P. borbonicum Ten-Hage, Turquet, Quod, Puiseux-Dao \& Couté, P. caipirignum Fraga, Menezes \& Nascimento, $P$. concavum Fukuyo, $P$. emarginatum Fukuyo, $P$. faustiae Morton, P. hoffmannianum Faust, P. lima (Ehrenberg) Stein, P. mexicanum Osorio-Tafall, $P$. texanum Henrichs, Steidinger, Scott \& Campbell, and $P$. leve Faust) have been confirmed to produce a suite of diarrhetic toxins, okadaic acid (OA) and the methyl derivatives dinophysistoxins (DTXs) (reviewed in Hoppenrath et al., 2013), of which nine are benthic (Murakami et al., 1982; Holmes et al., 2001; Hoppenrath et al., 2013,2014; Nascimento et al., 2016; Luo et al., 2017). The toxins that accumulated in molluscan shellfish are responsible for diarrhetic shellfish poisoning (DSP) in humans. Some species of Prorocentrum also produce various bioactive compounds (Faust and Gulledge, 2002; reviewed in Hoppenrath et al., 2013). While DSP toxins-producing Prorocentrum species have been recorded, reports of DSP incidents related to benthic Prorocentrum species were scarce, to our knowledge, only one DSP event from Patagonian Gulfs, Argentina has been reported to attribute to P. lima (Gayoso et al., 2002). Documentation on the occurrence and outbreaks of this particular poisoning have been proven difficult owing to its relatively generic

\footnotetext{
* Corresponding author.

E-mail address: cpleaw@um.edu.my (C.P. Leaw).
} 
symptoms as compared to other forms of shellfish poisonings (e.g., paralytic and amnesic shellfish poisonings), it is even difficult to detect the outbreaks of toxic Prorocentrum species, particularly of those with the benthic nature.

Species of the genus are generally identified morphologically based on the features of lateral plates and the periflagellar platelets (reviewed in Hoppenrath et al., 2013). However, sometimes the identity of species is uncertain since it cannot be readily determined, partly due to plasticity in the defined morphological traits and ambiguity in the original descriptions (Herrera-Sepúlveda et al., 2015; Chomérat et al., 2018). In this case, many species have been synonymized over the years: $P$. arabianum Morton \& Faust $(=P$. concavum Fukuyo) (Mohammad-Noor et al., 2007a; Mohammad-Noor et al., 2007b) and P. maculosum Faust ( $=P$. hoffmannianum Faust) (Rodríguez et al., 2018). But as yet, precise species identification is crucial in order to better understand the ecology of Prorocentrum species, as well as their toxicity. With the recent advancements of molecular phylogenetic, several new species of Prorocentrum have been erected (Murray et al., 2007; Chomérat et al., 2010; Henrichs et al., 2013; Han et al., 2016). Likewise, molecular data have been used in evaluating species crypticity of Prorocentrum, allowing better taxonomic decision, for example, the erection of $P$. caipirignum from the $P$. lima complex sensu lato (s.l.) (Nascimento et al., 2017).

Numerous studies have revealed high diversity of Prorocentrum in benthic reef ecosystems. In this study, a field survey was undertaken at the fringing coral reefs of Perhentian Islands Marine Park (Malaysia) to collect Prorocentrum isolates and to document their morphological characteristics. With that, a new morphotype was discovered. Phylogenetic reconstructions based on the nuclear-encoded ribosomal DNA in the large subunit (LSU) and the second internal transcribed spacer (ITS2) regions were used to infer phylogenetic relationships among Prorocentrum species found in this and other studies. The outcomes of the phylogenetic analyses supported our morphological observations that the morphotype is a distinct species, herein described as $P$. malayense sp. nov. Its ability to produce OA was assessed.

\section{Materials and methods}

\subsection{Sample collection and algal cultures}

Natural substrate samples such as seaweeds, coral rubble and sediment were collected via SCUBA diving at Perhentian Islands Marine Park, Terengganu, Malaysia (Table 1), with a range of water temperatures of $28-34{ }^{\circ} \mathrm{C}$ and salinity of 30-33. Samples were kept in one literbottles containing ambient seawater. In the laboratory, substrate samples were shaken vigorously to dislodge cells from the substrates. Samples were sieved through a $200 \mu \mathrm{m}$-mesh sieve and the filtrate was collected on a $10 \mu \mathrm{m}$-mesh sieve. The material retained was rinsed with filtered seawater into a polypropylene bottle. Single cells were isolated using a finely drawn glass Pasteur pipette under a Leica compound microscope (Leica Microsystems, Wetzlar, Germany). Cultures were grown in 96-well plates with the gradual addition of ES-DK medium (Kokinos and Anderson, 1995). Clonal cultures established were maintained in the medium at a salinity of $33,25 \pm 0.5^{\circ} \mathrm{C}$, light intensity of $70 \mu \mathrm{mol}$ photon $\mathrm{m}^{-2} \mathrm{~s}^{-1}$ under a $12: 12 \mathrm{~h}$ light: dark photocycle. The algal cultures established in this study were deposited in the Harmful Algal Culture Collection of Bachok Marine Research Station, Institute of Ocean and Earth Sciences, University of Malaya. Isolates of Prorocentrum used in this study are listed in Table 1.

\subsection{Morphological observations}

Standard terminology proposed by Hoppenrath et al. (2013) was adopted for morphological description. For light microscopy (LM) observation, cells were examined using a Leica DM3000 LED microscope (Leica Microsystems, Switzerland). Cell length and width of Prorocentrum were obtained by measuring at least 30 cells using the program Leica LAS ver.4.1 (Leica Microsystems). For fluorescence observation of the nucleus, samples were stained with SYTOX Green nucleic acid stain (Sigma Aldrich, St. Louis, USA), observed under an Olympus BX53 microscope, and images captured with an Olympus DP73 camera equipped with Cellsens Digital Image Software (Olympus, PA, USA).

Sample preparation for scanning electron microscopy (SEM) was as in Luo et al. (2017). The exponential phase-cultures were harvested by centrifugation $(1250 \times g$ for $10 \mathrm{~min})$ and the cell pellets were suspended in $60 \%$ ethanol for $1 \mathrm{~h}$ at $8{ }^{\circ} \mathrm{C}$. The cells were centrifuged again and the ethanol removed. The cell pellets were fixed for $3 \mathrm{~h}$ with $5 \%$ glutaraldehyde in filtered seawater, rinsed twice, and fixed with $2 \%$ $\mathrm{O}_{\mathrm{S}} \mathrm{O}_{4}$ overnight. The supernatant was removed; cells were placed on a coverslip coated with poly-L-lysine. The cells were washed with Milli-Q water for $10 \mathrm{~min}$ and underwent dehydration through a series of ethanol gradients $(10,30,50,70$ and $90 \%$, then three times in $100 \%$, 10 min each). Samples were later critical point-dried on a K850 Critical Point Dryer (Quorum/Emitech, West Sussex, UK), sputter-coated with gold, and examined with a Zeiss Sigma FE SEM (Carl Zeiss Inc., Oberkochen, Germany) or a Zeiss Ultra 55 FE SEM (Zeiss, Jena, Germany).

\subsection{DNA isolation and gene amplification}

All clonal cultures at the mid-exponential phase were harvested by centrifugation $(600 \times \mathrm{g}, 10 \mathrm{~min})$ and the genomic DNA was isolated as described in Leaw et al. (2001, 2010). In brief, cells were suspended in a lysis buffer containing $1 \%$ sodium dodecyl sulfate, $15 \mathrm{mM} \mathrm{NaCl}, 10 \mathrm{mM}$

Table 1

Prorocentrum isolates used in this study. -, not tested.

\begin{tabular}{|c|c|c|c|}
\hline Species & Strains & Location & Toxicity (fg cell ${ }^{-1}$ ) \\
\hline P. caipirignum & A10PR01 & Rawa Island, Perhentian Islands Marine Park, Malaysia & 3118 \\
\hline P. concavum & SS1201 & Rawa Island, Perhentian Islands Marine Park, Malaysia & - \\
\hline P. concavum & SP001 & Rawa Island, Perhentian Islands Marine Park, Malaysia & - \\
\hline P. cf. emarginatum & A10PR02 & Rawa Island, Perhentian Islands Marine Park, Malaysia & Not detectable \\
\hline P. cf. emarginatum & SS15S3 & Rawa Island, Perhentian Islands Marine Park, Malaysia & - \\
\hline P. cf. emarginatum & SS0657 & Rawa Island, Perhentian Islands Marine Park, Malaysia & - \\
\hline P. cf. foraminosum & IFR15-049 & Martinique Island, France & - \\
\hline P. lima & SS0905 & Rawa Island, Perhentian Islands Marine Park, Malaysia & 1044 \\
\hline P. lima & SP003 & Rawa Island, Perhentian Islands Marine Park, Malaysia & 1650 \\
\hline P. malayense & A10UK3 & Rawa Island, Perhentian Islands Marine Park, Malaysia & Not detectable \\
\hline P. malayense & TIO918 & Hainan Island, China & - \\
\hline P. mexicanum & A1049A1 & Rawa Island, Perhentian Islands Marine Park, Malaysia & Not detectable \\
\hline P. mexicanum & A1049A2 & Rawa Island, Perhentian Islands Marine Park, Malaysia & - \\
\hline P. mexicanum & A1049A9 & Rawa Island, Perhentian Islands Marine Park, Malaysia & - \\
\hline P. mexicanum & BNS003 & Batu Nisan, Perhentian Island Marine Park, Malaysia & - \\
\hline
\end{tabular}


EDTA (pH 8.0), and $10 \mathrm{mM}$ Tris-HCl (pH 7.5). Cetyltrimethylammonium bromide (1\%) was added and incubated at $55^{\circ} \mathrm{C}$. Subsequently, the mixture was extracted with chloroform: isoamyl alcohol (24:1), followed by standard phenol/chloroform procedure. DNA was precipitated in absolute ethanol and sodium acetate (pH 5.0) and rinsed with cold $70 \%$ ethanol. The DNA pellets were later dissolved in Tris-EDTA buffer ( $\mathrm{pH}$ 8.0).

LSU rDNA (D1-D3) was amplified using primer pair D1R and D3Ca (Scholin et al., 1994). The ITS region (ITS1-5.8S-ITS2) was amplified using primer pair ITS1F and ITS1R (Leaw et al., 2001). Amplification was performed using a peqSTAR Thermal Cycler (Peqlab Biotechnologie $\mathrm{GmbH}$, Erlangen, Germany). Thermal cycle procedures were as follows: LSU region: $94^{\circ} \mathrm{C}$ for 5 min followed by 35 cycles of $94^{\circ} \mathrm{C}$ for $30 \mathrm{~s}, 55^{\circ} \mathrm{C}$ for $30 \mathrm{~min}, 72^{\circ} \mathrm{C}$ for $1 \mathrm{~min}$, and a final extension at $72^{\circ} \mathrm{C}$ for $7 \mathrm{~min}$. ITS region: $94^{\circ} \mathrm{C}$ for $4 \mathrm{~min}$ followed by 35 cycles of $94^{\circ} \mathrm{C}$ for $30 \mathrm{~s}$, $50{ }^{\circ} \mathrm{C}$ for $45 \mathrm{~min}, 72^{\circ} \mathrm{C}$ for $1 \mathrm{~min} 30 \mathrm{~s}$ and a final extension of $72{ }^{\circ} \mathrm{C}$ for $7 \mathrm{~min}$. Purified amplicons were directly sequenced for both strands.

\subsection{LSU rDNA phylogenetic reconstruction}

Sequences obtained for LSU rDNA (D1-D3) were aligned with the related sequences from GenBank (Supplementary Table S1) using MUSCLE, Multiple Sequence Comparison by Log-Expectation (Edgar, 2004). The LSU dataset comprised of 53 nucleotide sequences and six outgroup taxa (Takayama helix, Peridiniella catenata, Brachidinium capitatum, Karenia selliformis, Karenia brevis and Karenia mikimotoi). Maximum parsimony (MP) and maximum likelihood (ML) analyses were performed using PAUP ver. 4.0b10 (Swofford, 2000). ML was performed with a heuristic search and tree-bisection-reconnection. The best evolutionary model of nucleotide substitution was obtained from jModelTest 2.1.10 (Posada, 2008; Darriba et al., 2012), with the best substitution and rate heterogeneity models of TIM1 + G selected for both $\mathrm{ML}$ and $\mathrm{BI}$ (parameter values set: $\mathrm{A}=0.2503, \mathrm{C}=0.2028$, $\mathrm{G}=0.3008, \mathrm{~T}=0.2461$; rate matrix of $\mathrm{A}-\mathrm{C}=1.0000, \mathrm{~A}-\mathrm{G}=2.9645$, $\mathrm{A}-\mathrm{T}=0.7874, \mathrm{C}-\mathrm{G}=0.7874, \mathrm{C}-\mathrm{T}=7.7961, \mathrm{G}-\mathrm{T}=1.0000$, with a gamma shape parameter of 0.6430). Bayesian inference (BI) was performed using MrBayes 3.2 (Ronquist et al., 2012). Four simultaneous Markov chain Monte Carlo of $1 \times 10^{6}$ generations were run and sampled at every 1000 generations. Convergence diagnostics were graphically estimated using Tracer ver. 1.5 and the first $25 \%$ of burn-in trees were discarded. Posterior probability at each clade was estimated from a majority rule consensus tree. Pairwise genetic distances (uncorrected p-distance) were estimated using MEGA 6.06 (Tamura et al., 2013).

\subsection{ITS2 transcript modeling and phylogenetic analyses}

The ITS2 secondary structure of $P$. malayense was modeled based on the 5.8S-28S interaction to form a proximal stem (Keller et al., 2009). Free energy minimization prediction was performed using RNAstructure ver. 5.8.5 (Reuter and Mathews, 2010) and Vienna RNA secondary structure server (Hofacker, 2003). Four helices were formed with a universal motif pyrimidine-pyrimidine (U-U) mismatch on the second helix (Wolf et al., 2005). The multiple sequence-structure alignment was generated using 4SALE ver. 1.7 (Seibel et al., 2006, 2008). ITS2 structure was documented in dot-bracket form and illustrated using VARNA ver. 3.93 (Darty et al., 2009). The CBCAnalyzer option implemented in 4SALE was used to analyze the numbers of compensatory base changes (CBCs; Wolf et al., 2005).

The ITS2 phylogenetic tree was constructed based on Schultz and Wolf (2009) and Keller et al. (2010). The ITS2 transcripts of Takayama acrotrocha and Karenia mikimotoi were used as the outgroup. Alignment of orthologous sequences was guided by the secondary structure of ITS2 simultaneously, using 4SALE v1.7 (Wolf et al., 2005; Seibel et al., 2006, 2008) with a specific $12 \times 12$ scoring matrix (Wolf et al., 2014). The ITS2 sequence-structure alignment data file with sequence-structure information was used to construct neighbor joining (NJ) and MP trees as in Teng et al. (2016). ML analysis was performed using Phangorn (Schliep, 2010) in the statistical framework R ( $\mathrm{R}$ Development Core Team 2011), with the command script available via 4SALE (Wolf et al., 2014) and a non-parametric bootstrap analysis as described in Leaw et al. (2016).

\subsection{Determination of okadaic acid (OA) and dinophysistoxins (DTXs)}

Six strains of Prorocentrum species (Table 1) were used for OA analysis. Cultures were harvested during the exponential phase by centrifugation $(1250 \times g, 10 \mathrm{~min})$. Cell pellets were resuspended in $500 \mu \mathrm{l}$ of methanol and homogenized with $0.9 \mathrm{~g}$ of lysing matrix D by reciprocal shaking at maximum speed $\left(6.5 \mathrm{~ms}^{-1}\right)$ for $45 \mathrm{~s}$ in a Bio101 FastPrep instrument (Thermo Savant, Illkirch, France). Subsequently, each sample was centrifuged at $16,100 \times g$ at $4{ }^{\circ} \mathrm{C}$ for $15 \mathrm{~min}$. The supernatant was transferred to a spin-filter $(0.45 \mu \mathrm{m}$ pore-size, Millepore Ultrafree, Eschborn, Germany) and centrifuged at $800 \times g$ for $30 \mathrm{~s}$, followed by transfer to autosampler vials. Analysis of multiple lipophilic toxins including OA, DTX-1, and DTX-2 was performed using liquid chromatography coupled with tandem mass spectrometry (LC-MS/MS) on a Sciex 4000 Q Trap triple-quadrupole mass spectrometer (Sciex, Darmstadt, Germany) as described in Krock et al. (2008).

\section{Results}

\subsection{Morphology of Prorocentrum species}

Thirteen isolates of Prorocentrum were established in this study (Table 1); twelve were identical to five previously described species: $P$. lima (Ehrenberg) Stein, P. caipirignum Fraga, Menezes and Nascimento, $P$. concavum Fukuyo, $P$. cf. emarginatum Fukuyo, and $P$. mexicanum Osorio-Tafall. Prorocentrum caipirignum is described for the first time from the south-western Pacific region. Morphological features of the five species are comparable to those previously described (reference herein); the description of each species is detailed in this section.

In this study, a new morphotype was discovered from Rawa Island, Perhentian Islands Marine Park. This morphotype was also encountered from Hainan Island, China. Morphological and molecular data together support the recognition of Prorocentrum malayense sp. nov., a new species closely related to species in Clade A sensu Chomérat et al. (2018).

3.1.1. Prorocentrum malayense Lim, Z.F., Leaw, Lim, P.T. sp. nov. (Fig. 1, Table 2)

Description: Cells are elliptical in shape with a depression in the central region of the right plate. Cells are symmetrical, 37.6-44.7 $\mu \mathrm{m}$ long $(40.8 \pm 1.9 \mu \mathrm{m}, n=30)$ and $31.4-38.9 \mu \mathrm{m}$ wide $(36.6 \pm 2.0 \mu \mathrm{m}$, $n=30$ ). A pyrenoid is present, located at the central part of the cell (Fig. 1A). Chloroplasts are located around the lateral and posterior regions (Fig. 1B). The nucleus is located posteriorly (Fig. 1C). Thecal ornamentation is foveate. Small and round thecal pores are scattered throughout the lateral plates, except in the central part of the plates (Figs. 1D-F). Cells possess 201-203 thecal pores per plate $(n=7)$, with the diameter of $0.17-0.37 \mu \mathrm{m}(0.23 \pm 0.04 \mu \mathrm{m}, n=28)$ and located in shallow depressions (Fig. 1G). A ring of densely arranged marginal pores is present on both lateral plates, but the pores are not evenly spaced. The numbers of marginal pores ranged in 108-115 per plate (Figs. 1E-F). The intercalary band is horizontally striated (Fig. 1H, I). Cells form chains in a hyaline envelope (Fig. 1I). The V-shaped periflagellar area lacks special ornamentation (such as wing spine, curved projection, deep depression); $4 \mu \mathrm{m}$ long and $5 \mu \mathrm{m}$ wide. It comprised of nine platelets (1a, 1b, 2, 3, 4, 5, 6, 7, and 8) (Figs. 1J-K). The accessory pore (ap) is smaller than the flagellar pore (fp) (Fig. 1J). The first four platelets (1a, 2, 3, and 4) are larger in size and occupying the anterior region. Platelet 1 is extended to the posterior end, which formed two parts: platelets 1a and $1 \mathrm{~b}$ (Figs. $1 \mathrm{~J}-\mathrm{K}$ ). Platelet 1a is large, bearing a 

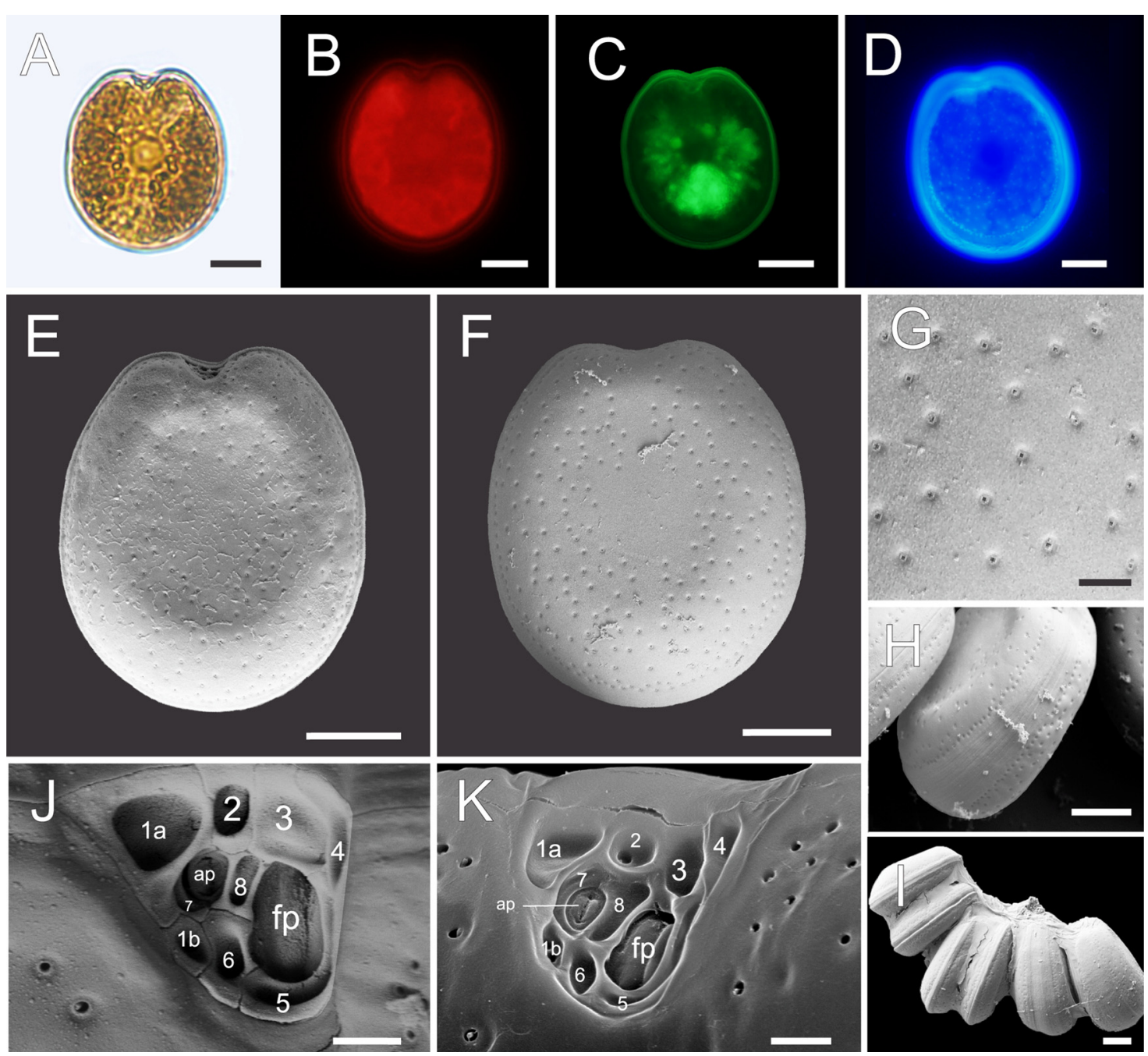

Fig. 1. Prorocentrum malayense. LM, a cell showing the positions of the pyrenoid (A), chloroplasts (B), nucleus (C), and marginal pores (D). SEM, (E) right thecal plate, (F) left thecal plate, (G) surface ornamentation, (H) horizontally striated intercalary band, (I) cells divided in hyaline chain envelope, (J-K) V-shaped periflagellar area with nine platelets. Scale bars, $10 \mu \mathrm{m}(\mathrm{A}-\mathrm{F}, \mathrm{H}, \mathrm{I}) ; 2 \mu \mathrm{m}(\mathrm{G}) ; 1 \mu \mathrm{m}(\mathrm{J}-\mathrm{K})$.

large depression (Fig. 1J). Platelet $1 \mathrm{~b}$ is adjacent to platelet 6 and 7. Platelet 2 is the most anterior platelet, rectangular in shape with a central depression. Platelet 3 is broad, calabash-like shaped, smaller at the sagittal margin and broadening towards the margin of the fp. The Jshaped platelet 5 covers the left posterior half of the periflagellar area, surrounding the fp. Platelet 6 is longer than wide, irregular hexagonal in shape adjacent to $1 \mathrm{~b}, 7,8$, fp, and 5 . The C-shaped platelet 7 is narrow, surrounding almost half of the ap. Platelet 8 is small, longer than wide, separating the fp from ap (Figs. 1J, K) ().

Type Locality: Rawa Island, Terengganu $\left[5^{\circ} 57^{\prime} 44.45^{\prime \prime} \mathrm{N}\right.$, $\left.102^{\circ} 40^{\prime} 53.26^{\prime \prime} \mathrm{E}\right]$

Holotype: SEM stub of strain A10UK3, designated as TIO201704 and illustrated in Fig. 1E, is deposited in the Third Institute of Oceanography, State Oceanic Administration, Xiamen 361005, China.

Etymology: The epithet "malayense" refers to the Malay Archipelago.

Molecular characterization: Nucleotide sequences of LSU rDNA (D1-D3) and ITS1-5.8S-ITS2 of strain A10UK3 were deposited in GenBank, with accession number MG600143 and MG600149, respectively.

\subsubsection{Prorocentrum concavum (Fig. 2)}

Cells are symmetrical, broad and oval in shape. Cells are 43.2-51.27 $\mu \mathrm{m}$ long ( $46.5 \pm 1.7 \mu \mathrm{m}, n=30)$ and $38.2-48.2 \mu \mathrm{m}$ wide $(41.5 \pm 2.1 \mu \mathrm{m}, n=30)$. A depression is observed in the center of the right lateral plate where pores are absent (Fig. 2A). The thecal surface is reticulate-foveate with scattered pores (Figs. 2A-B). Two size classes of thecal pores are observed, with the absence of marginal pore (Fig. 2C), thecal pore density increased as it approaches the marginal area (Figs. 2A-B). Smaller pores are denser around the periflagellar area. The periflagellar area is broadly $\mathrm{V}$-shaped, with nine platelets observed (Fig. 2D). Flagellar pore, fp is slightly larger than ap (Fig. 2D).

\subsubsection{Prorocentrum caipirignum (Fig. $3 A-G$ )}

Cells are elliptical and symmetrical, 38.6-47.2 $\mu \mathrm{m}$ long $(43.3 \pm 1.8 \mu \mathrm{m}, n=30)$ and $31.5-37.5 \mu \mathrm{m}$ wide $(34.5 \pm 1.6 \mu \mathrm{m}, n=$ 30). A pyrenoid is present (Fig. 3A), with numerous chloroplasts distributed in the cell (Fig. 3B). The nucleus is located posteriorly and almost round in shape (Fig. 3C). A minor depression appears from the periflagellar area to the central region (Fig. 3D). The thecal ornamentation is smooth with scattered kidney-shaped thecal pores (Figs. 3D-E). The central part of the lateral plates is devoid of pores. Marginal pores are evenly spaced and compact (Figs. 3D-E). The intercalary band is smooth with horizontal striation (Fig. 3F). The periflagellar area is broadly V-shaped, collar and platelet lists are present. There are eight platelets $(1,2,3,4,5,6,7,8)$ in the periflagellar area, with a small ap and a large fp (Fig. 3G). A suture is observed between platelets 2 and 8 (Fig. 3G). 
Table 2

Morphological characteristics of Prorocentrum malayense sp. nov. and its closely related species. NA, data not available.

\begin{tabular}{|c|c|c|c|c|c|c|}
\hline Characters & P. malayense & P. $\operatorname{leve}^{1,3,6,7,8}$ & P. concavum $^{4,5,8,9,10,11,13}$ & P. foraminosum $4,5,6,8,9,10,11$ & $\begin{array}{l}P . c f . \\
\text { foraminosum }^{2}\end{array}$ & $\begin{array}{l}P . \text { sp. aff. } \\
\text { foraminosum }^{12}\end{array}$ \\
\hline Cell shape & Oval & Broad oval & Broad oval to ovoid & Oval or circular ${ }^{10}$ & oblong oval & oblong oval \\
\hline Cell symmetry & Symmetric & Symmetric & Symmetric & Symmetric & Symmetric & Symmetric \\
\hline Length $(\mu \mathrm{m})$ & $38.1-44.7$ & $40-49^{7,8}$ & $38-55^{4,10}$ & $46-66^{4}, 32-34^{10}$ & $43-49$ & $39-56$ \\
\hline Width $(\mu \mathrm{m})$ & $31.4-38.0$ & $33-40^{7,8}$ & $35-48^{4,10}$ & $31-42^{4}, 29-31^{10}$ & $30-36$ & $24-40$ \\
\hline \multicolumn{7}{|l|}{ Periflagellar area } \\
\hline Periflagellar shape & V-shaped & U-shaped & V-shaped & wide V-shaped & narrow V-shaped & V-shaped \\
\hline Collar on left plate & No & No & Yes & No & No & No \\
\hline Thick flange & No & No & No & No & No & No \\
\hline Wing-shaped spine & No & No & No & No & No & No \\
\hline Protrusions & No & No & No & No & No & No \\
\hline Number of platelets & 9 & $7-9$ & $8-9$ & 9 & 9 & 9 \\
\hline Platelet division & $1 \mathrm{a}, 1 \mathrm{~b}$ & $6 a, 6 b$ & $6 a, 6 b$ & $1 \mathrm{a}, 1 \mathrm{~b}$ & $1 \mathrm{a}, 1 \mathrm{~b}$ & $6 a, 6 b$ \\
\hline Shape of platelet 6 & $\begin{array}{l}\text { Irregularly } \\
\text { hexagonal }\end{array}$ & Elongated & Irregular & Irregular & $\begin{array}{l}\text { Rectangular, } \\
\text { small }\end{array}$ & Irregular \\
\hline Shape of platelet 8 & $\begin{array}{l}\text { Irregularly } \\
\text { pentagonal }\end{array}$ & $\begin{array}{l}\text { Irregularly } \\
\text { pentagonal }\end{array}$ & $\begin{array}{l}\text { Irregular, anterior semi rod } \\
\text { shaped }\end{array}$ & $\begin{array}{l}\text { Irregularly hexagonal, edge } \\
\text { curved inwards }\end{array}$ & Irregular & $\begin{array}{l}\text { Irregularly hexagonal, } \\
\text { edge curved inwards }\end{array}$ \\
\hline Flagellar pore & Yes & Yes & Yes & Yes & Yes & Yes \\
\hline Accessory pore & Yes & Yes & Yes & Yes & Yes & Yes \\
\hline \multicolumn{7}{|l|}{ External features } \\
\hline $\begin{array}{l}\text { Theca ornamentation } \\
\text { Pore pattern }\end{array}$ & $\begin{array}{l}\text { Foveate } \\
\text { scattered }\end{array}$ & $\begin{array}{l}\text { Partly foveate }{ }^{1} \\
\text { scattered }\end{array}$ & $\begin{array}{l}\text { Foveate } \\
\text { scattered }\end{array}$ & $\begin{array}{l}\text { Foveate } \\
\text { scattered }\end{array}$ & $\begin{array}{l}\text { Foveate } \\
\text { scattered }\end{array}$ & $\begin{array}{l}\text { Foveate } \\
\text { scattered }\end{array}$ \\
\hline Thecal pores & $201-203$ & $\begin{array}{l}211-222,221- \\
238\end{array}$ & $340-485$ & $270-350$ & $275-320$ & $344-387$ \\
\hline Marginal pore & Yes (108-115) & $\begin{array}{l}\text { Yes }(105 \text {, } \\
99-130)\end{array}$ & No & No & No & No \\
\hline Plate centre & Devoid of pores & Devoid of pores & Devoid of pores & Devoid of pores & Devoid of pores & Devoid of pores \\
\hline Small pore $(0-0.15 \mu \mathrm{m})$ & No & Yes & Yes & Yes & Yes & Yes \\
\hline $\begin{array}{l}\text { Large pore } \\
\qquad(0.15-0.80 \mu \mathrm{m})\end{array}$ & Yes & Yes & Yes & Yes & Yes & Yes \\
\hline Intercalary band & $\begin{array}{l}\text { Horizontally } \\
\text { striated }\end{array}$ & $\begin{array}{l}\text { Transversely } \\
\text { striated }\end{array}$ & Smooth or granulated & Smooth with no striation & NA & $\begin{array}{l}\text { Horizontal and } \\
\text { transverse striation }\end{array}$ \\
\hline \multicolumn{7}{|l|}{ Organelles } \\
\hline Pyrenoid & Yes & Yes & Yes & NA & NA & NA \\
\hline Nucleus shape & $\begin{array}{l}\text { Round to U- } \\
\text { shaped }\end{array}$ & NA & Round to oval & NA & NA & NA \\
\hline $\begin{array}{l}\text { Nucleus position } \\
\text { Cell division }\end{array}$ & Posterior & Posterior & Posterior & Posterior & Posterior & Posterior \\
\hline $\begin{array}{l}\text { Formation of hyaline } \\
\text { envelope }\end{array}$ & Yes & Yes & No & Yes & NA & Yes \\
\hline
\end{tabular}

1 Aligizaki et al. (2009a).

2 Chomerat et al. (2018).

3 David et al. (2014).

4 Faust (1990).

5 Faust, (1993a,1993b).

6 Faust (1999).

7 Faust et al. (2008).

8 Hoppenrath et al. (2013).

9 Hoppenrath et al. (2014).

10 Mohammad-Noor et al. (2007a), Mohammad-Noor et al. (2007b).

11 Morton et al. (2002).

12 Selina, 2017.

13 Fukuyo (1981).

\subsubsection{Prorocentrum lima (Fig. $3 H-K$ )}

Cells are oval and symmetrical (Figs. 3H-I), 33.5-41.3 $\mu \mathrm{m}$ long and $25.4-34.7 \mu \mathrm{m}$ wide $(29.9 \pm 1.8 \mu \mathrm{m}, n=30)$. Thecal pores are scattered on both plates but absent from the center part of the plate, both round and ovoid shaped pores were observed (Figs. 3H-I). Marginal pores present; the intercalary band is transversely striated (Fig. 3J). The periflagellar area is V-shaped (Fig. 3K). Eight to nine platelets (1, 2, 3, $4,5,6,7 \mathrm{a}, 7 \mathrm{~b}, 8)$ are observed in the periflagellar area; folds were formed on platelet 4 and sometimes on platelet 6 (Fig. 3K). In some cells, platelets $7 \mathrm{a}$ and $7 \mathrm{~b}$ are observed (Fig. $3 \mathrm{~K}$ ).

\subsubsection{Prorocentrum cf. emarginatum (Fig. 4)}

Cells are broad, round to oval and asymmetrical (Fig. 4A, D-E). Cells are $32.9-42.9 \mu \mathrm{m}$ long $(38.2 \pm 2.4 \mu \mathrm{m}, n=30)$ and $27.1-39.0 \mu \mathrm{m}$ wide (35.1 $\pm 3.0 \mu \mathrm{m}, n=30)$. A pyrenoid is absent. Chloroplasts are small, rod-shaped and packed throughout the cell (Fig. 4B). The nucleus is bean-shaped and located at the posterior part of the cell (Fig. 4C). Thecal pores appear in a radial pattern throughout the plate but are absent from the central region (Fig. 4D). The apical "shoulder" tips are different in shape, the dorsal tip is broader and semi-circular, while the ventral tip is narrow and cone-shaped (Fig. 4E). Marginal pores are absent, but pores are arranged in a more compact pattern near the marginal area. The intercalary band is transversely striated (Fig. 4F). A wing-shaped spine covers about $1 / 3$ of the right side of the periflagellar area (Fig. 4G); two sizes of thecal pores are observed. Thecal ornamentation is smooth whereby depression is observed around smaller pores but not in the larger pores (Fig. 4G).

3.1.6. Prorocentrum mexicanum (Fig. 5)

Cells are elliptical in shape and asymmetrical (Fig. 5A), 

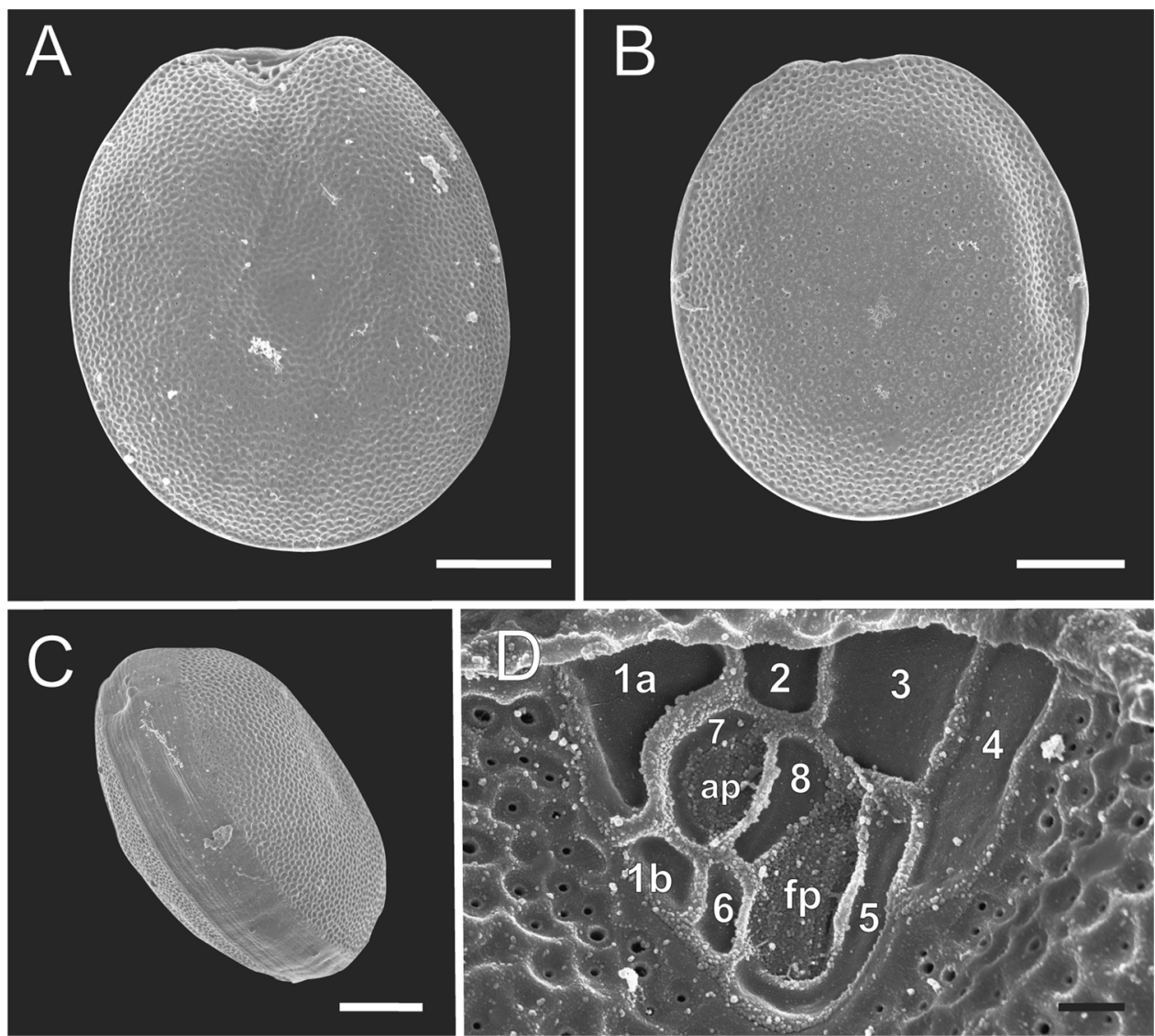

Fig. 2. Prorocentrum concavum. SEM, (A) right thecal plate, (B) left thecal plate, (C) lateral view showing the intercalary band, (D) periflagellar area with nine platelets. Scale bars, $10 \mu \mathrm{m}$ (A-C); $2 \mu \mathrm{m}$ (D).

29.5-35.0 $\mu \mathrm{m}$ long $(32.2 \pm 1.1, n=30)$ and $20.8-26.0 \mu \mathrm{m}$ wide $(23.6 \pm 1.3, n=30)$. A pyrenoid is not visible under LM. The chloroplast is globular (Fig. 5B) and the nucleus is round (Fig. 5C). Pores are dispersed radially, pores are also observed at the anterior marginal end (Fig. 5D). Thecal ornamentation is smooth (Fig. 5E, G). Depressions are observed around large pores but not on small pores (Fig. 5G). The intercalary band is smooth without striation (Fig. 5F). The apical spine is located in the periflagellar area, next to the shorter apical shoulder. Seven platelets are observed (Fig. 5G).

\subsection{Genetic divergence and molecular phylogeny of Prorocentrum}

The pairwise comparisons of the LSU rDNA and ITS2 uncorrected $p$ distances of $P$. malayense and its closely related species $(P$. sp. aff. foraminosum, $P$. cf. foraminosum, $P$. leve and $P$. concavum) are depicted in Supplementary Tables S3 and S4, respectively. The pairwise distances revealed significant interspecific divergences between $P$. malayense and its closely related species (LSU, 13-23\%; ITS2, 45-64\%).

The LSU rDNA dataset yielded identical tree topologies for all analyses, with the BI tree shown (Fig. 6). The alignment profile yielded 493 characters, of which 275 were parsimony informative and 164 were constant. The resulting LSU tree revealed sister relationship of $P$. malayense and $P$. leve, but with moderate nodal supports (MP/ML/BI: 76/54/0.79).

A total of 41 ITS2 transcripts of Prorocentrum were modeled, of which five were newly generated sequences $(P$. malayense A10UK3, $P$. cf. foraminosum IFR15-049, P. caipirignum A10PR01, $P$. mexicanum A1049A1, and P. cf. emarginatum A10PR02), and the remainder were retrieved from the GenBank nucleotide database (Supplementary Table S2). The ITS2 sequence-structure dataset yielded 257 columns. The ITS2 phylogenetic tree also supported the monophyly of $P$. malayense
(MP/ML/NJ: 96/100/79) (Fig. 7A).

In the LSU tree, the Malaysian P. caipirignum strain A10PR01 was grouped with other strains of $P$. caipirignum from Cuba (JQ638940), China (KY010253), and a strain previously designated as $P$. arenarium Faust (K-0625, EF566747; Mohammad-Noor et al., 2007a), forming a sister group with $P$. lima morphotype 5 . Also, in the ITS2 tree, the strain was grouped with two other strains of $P$. caipirignum, forming a sister group with $P$. hoffmannianum complex.

The Malaysian strain of $P$. lima (SS0905) was clustered with strains of $P$. lima morphotype 1 (cf. Zhang et al., 2015) in the LSU tree (Fig. 6). The Malaysian strains of $P$. cf. emarginatum and $P$. mexicanum were clustered with their respective taxa in both LSU and ITS2 trees (Figs. 6, 7A).

The ITS2 transcript of $P$. malayense is shown in Fig. 7B, with the ITS2 transcript length of 204 bases, which is shorter than that of $P$. leve (218 bases) and $P$. cf. foraminosum (236 bases) (Table 3). The universal motif of pyrimidine-pyrimidine (U-U) was found in helix II (Fig. 7B). Pairwise ITS2 comparisons between $P$. malayense and $P$. leve revealed two CBCs at helix III and five HCBCs (four at helix I and one at helix III, respectively), with 74 single nucleotide polymorphisms and 62 indels (Fig. 7B).

\subsection{Okadaic acid production by Prorocentrum}

Three species tested ( $P$. malayense, P.cf. emarginatum, and $P$. mexicanum) did not show detectable levels of OA, DTX-1 nor DTX-2, with the limit of detection (LOD) of approximately $5 \times 10^{-4} \mathrm{pg}$ cell ${ }^{-1} \mathrm{de}-$ pending on the individual response factor of each toxin and the exact amount of cells analyzed. Only $P$. lima and $P$. caipirignum produced OA at a cell quota of 1.0-1.6 and $3.1 \mathrm{pg}^{\text {cell }}{ }^{-1}$, respectively (Table 1 ). 

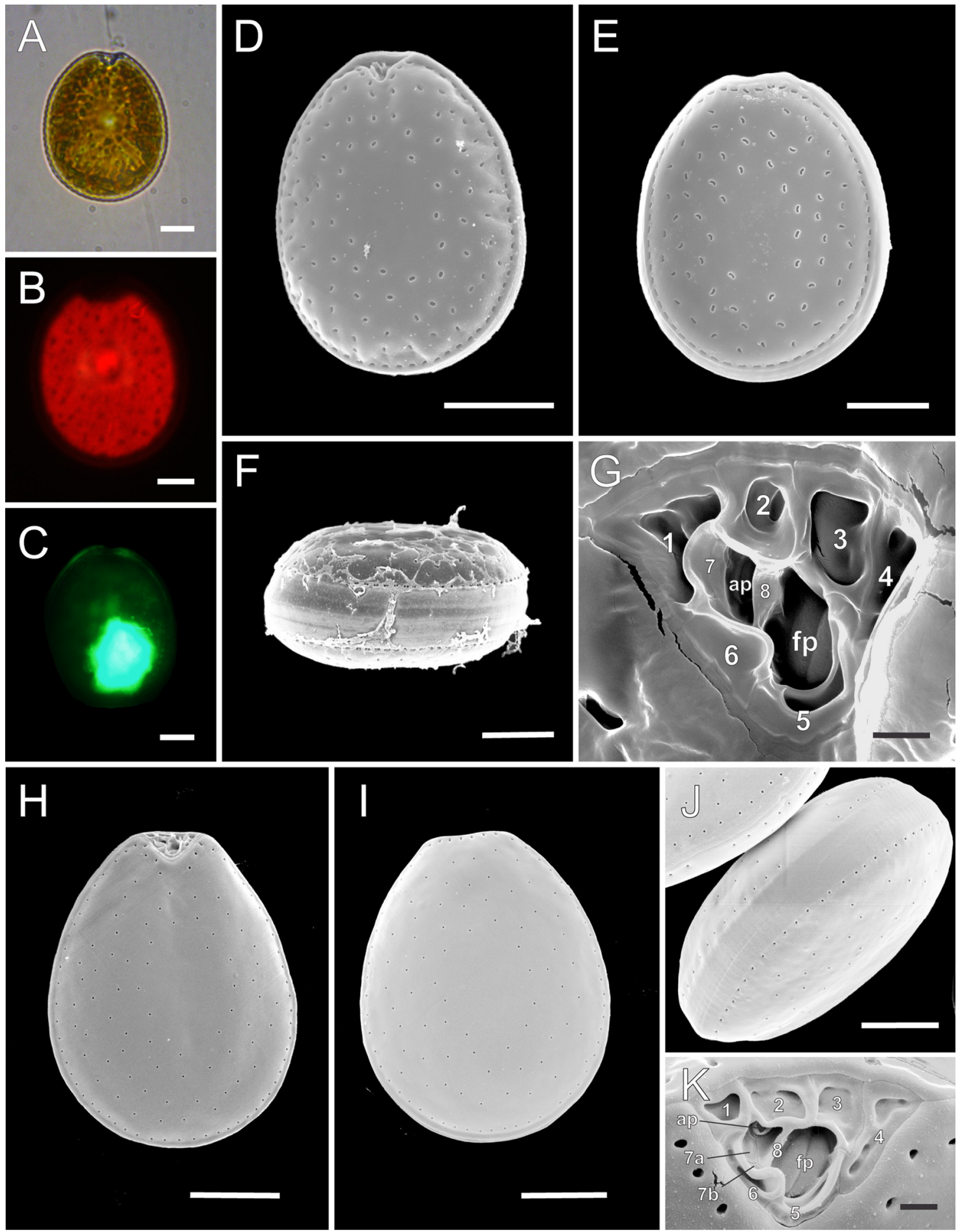

Fig. 3. Prorocentrum caipirignum (A-G). LM, a cell showing pyrenoid (A), chloroplast (B) and nucleus (C). SEM, plates with marginal pores and smooth surface, with depression at center region (D, E), horizontally striated intercalary band (F), and the periflagellar area (G). Prorocentrum lima (H-K). SEM, (H) right thecal plate, (I) left thecal plate, (J) lateral view showing the intercalary band, (K) periflagellar area with nine platelets. Scale bars, $20 \mu \mathrm{m}(A-C) ; 10 \mu \mathrm{m}(\mathrm{D}-\mathrm{J}) ; 1 \mu \mathrm{m}(\mathrm{G}, \mathrm{K})$.

\section{Discussion}

4.1. Morphological and molecular distinction between $P$. malayense and its closely related species

The description of $P$. malayense is supported by morphological and molecular data. Prorocentrum malayense possesses morphological characteristics common to Clade A sensu Chomérat et al. (2018). Schematic drawings are presented in Fig. 8 to illustrate the differences between $P$. malayense and its morphologically similar taxa ( $P$. leve, $P$. foraminosum s.l. and $P$. concavum). Generally, the species can be easily distinguished from $P$. leve, $P$. foraminosum s.l. and $P$. concavum based on cell shape and ornamentation, and the characteristics of periflagellar area (see Fig. 1, Fig. 8). The species is differentiated from its phylogenetically closest sister taxon, $P$. leve, by having an elliptical lateral plates; $P$. leve is broadly oval in shape (Fig. 8, this study; Faust et al., 2008; David et al., 2014; Mertens et al., 2017). The two species shared similar plate features, such as randomly distributed pores with foveate ornamentation, 


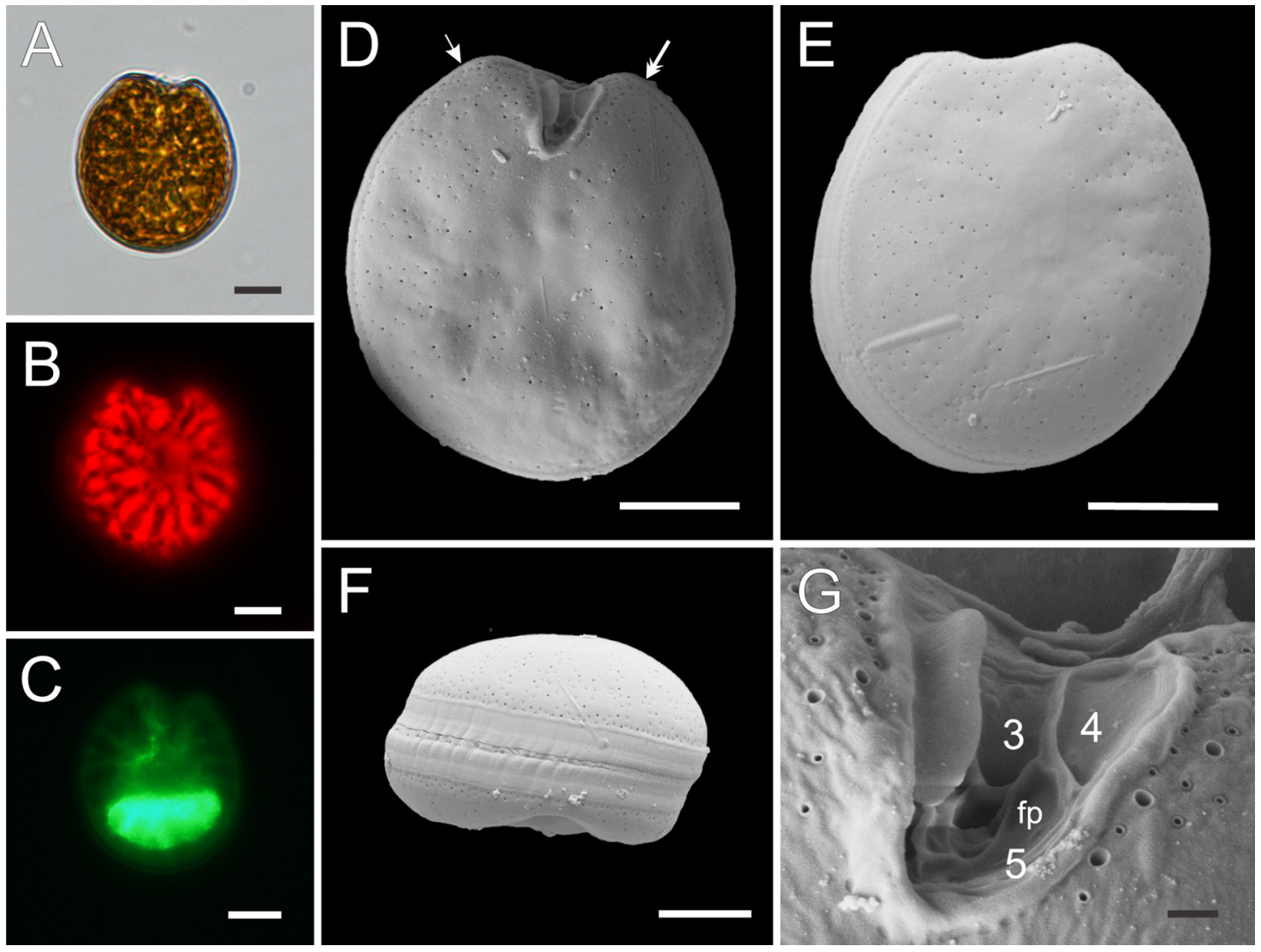

Fig. 4. Prorocentrum cf. emarginatum. LM, a cell showing chloroplast arrangement (A-B) and nucleus position (C). SEM, right plate showing dorsal apical tip (single arrowhead) and ventral apical tip (double arrowhead) (D), left plate (E), the transversely striated intercalary band (F), periflagellar area (G). Scale bars, $20 \mu \mathrm{m}(A-C)$; $10 \mu \mathrm{m}(\mathrm{D}-\mathrm{F}) ; 1 \mu \mathrm{m}(\mathrm{G})$.

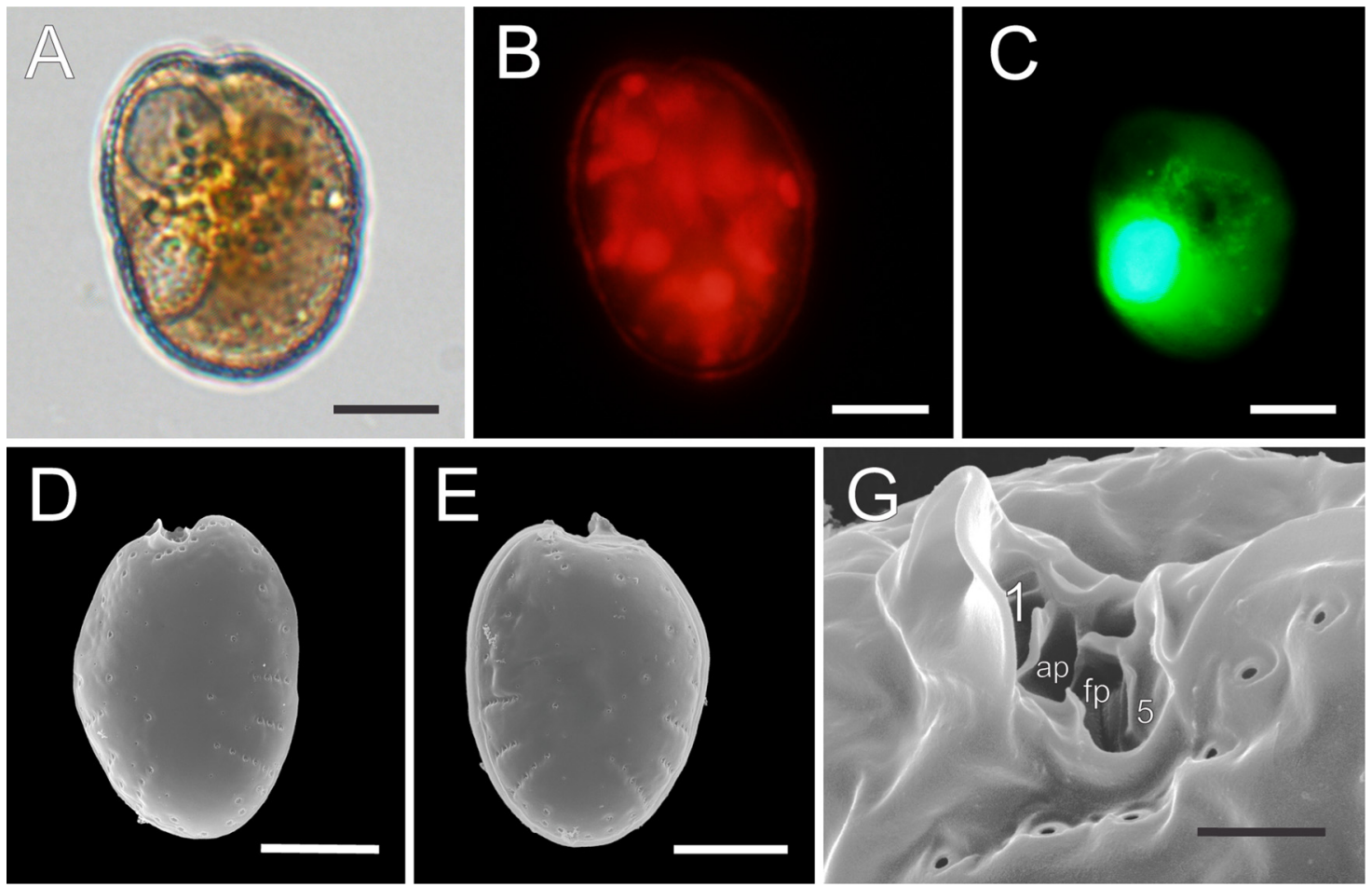

Fig. 5. Prorocentrum mexicanum. LM, a cell showing chloroplast arrangement (A-B), nucleus position (C). SEM, thecal plates (D-E) and periflagellar area (F). Scale bars, $10 \mu \mathrm{m}(\mathrm{A}-\mathrm{E}) ; 1 \mu \mathrm{m}(\mathrm{F})$. 


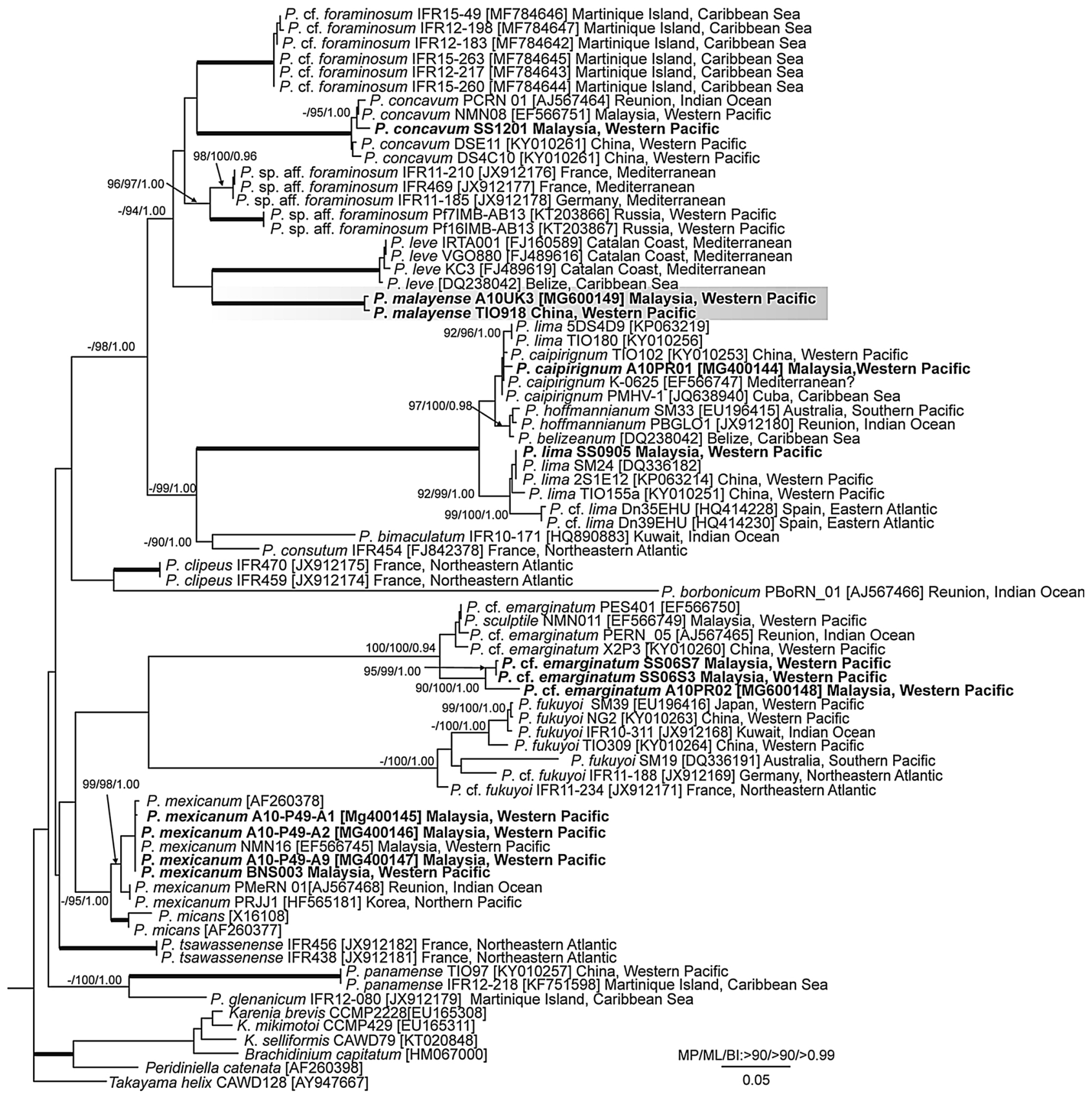

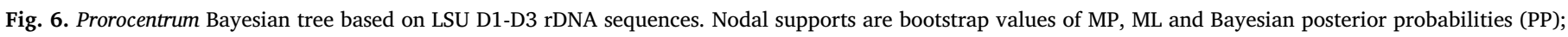

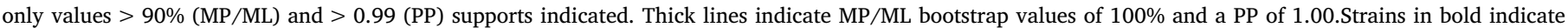
sequences obtained in this study.

and the presence of marginal pores. However, the number of thecal pores between the two species differs: $P$. malayense has a lower range of thecal pore density (Table 2, this study; Faust et al., 2008; David et al., 2014). Pore density, however, has been regarded as an extremely variable trait and might not be suitable as a morphologically informative feature (Aligizaki et al., 2009; David et al., 2014). The pore size of $P$. malayense $(0.23 \pm 0.04 \mu \mathrm{m})$ is larger than that of $P$. leve $(0.15 \pm 0.02 \mu \mathrm{m}$; Table 2$)$. The latter was reported with minute pores: $0.05-0.10 \mu \mathrm{m}$ (David et al., 2014), but such a feature was not observed in $P$. malayense. Cells of $P$. leve show the presence of a cusp at the apical end of the right plate (Faust et al., 2008) but this feature was not observed in $P$. malayense.

Platelet arrangement and patterns on the periflagellar area are often used to support the delineation of Prorocentrum species, such as $P$. caipirignum and P. lima (Nascimento et al., 2017). As in this study, distinct patterns were observed between $P$. malayense and its most closely related taxon, $P$. leve (Fig. 8). Prorocentrum malayense is readily delineated from $P$. leve by the length: width ratio of the periflagellar area: $P$. malayense is more deeply excavated $(\mathrm{L}: \mathrm{W}, 0.8)$ as compared to $P$. leve (L:W, 0.5-0.6), which is wide and U-shaped (Faust et al., 2008; David et al., 2014). The position of the accessory pore (ap) is higher than flagellar pore (fp) in $P$. malayense but is at the obverse position in $P$. leve (Fig. 8). Nine platelets were identified in $P$. malayense, with a large platelet $1 \mathrm{a}$ that extends to the posterior end and a small rectangular platelet 1b (see Fig. 1, Fig. 8), while David et al. (2014) reported only eight platelets in P. leve. On the other hand, Mertens et al. (2017) reported platelets $6 \mathrm{a}$ and $6 \mathrm{~b}$ in $P$. leve. Platelet 8 of $P$. malayense was shorter than that of $P$. leve. Accordingly to David et al. (2014), platelets $8 \mathrm{a}$ and $8 \mathrm{~b}$ were occasionally observed in $P$. leve, but $P$. malayense only possesses platelet 8 . The horizontal striation of the intercalary band of 

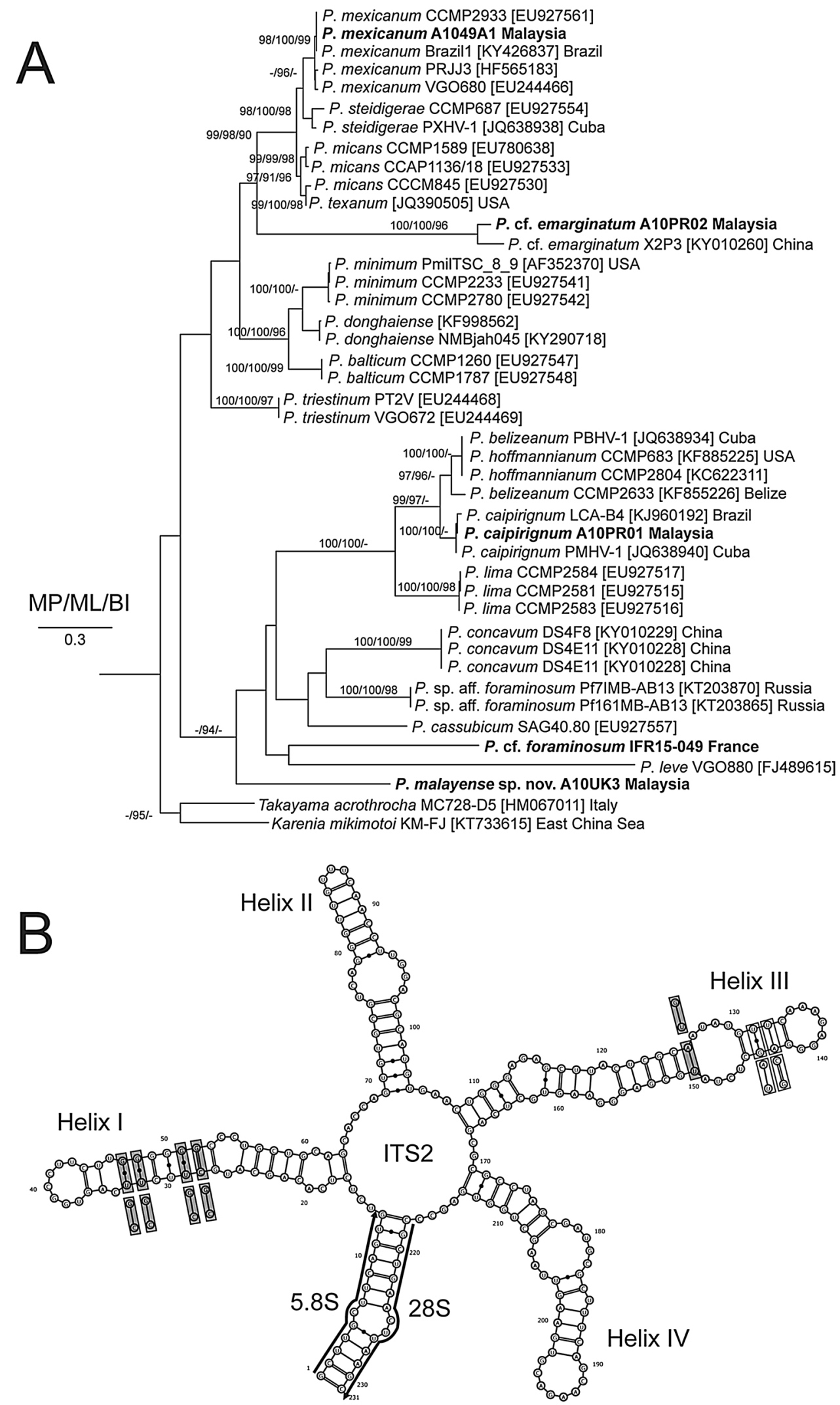

Fig. 7. (A) Prorocentrum ML tree based on ITS2 sequence-structure data set. Nodal supports are bootstrap values of MP/ML ( $>90 \%)$ and NJ ( $>70 \%)$. Thick lines indicate MP/ML bootstrap values of $100 \%$ and a PP of 1.00 . Strains in bold indicate sequences obtained in this study. (B) ITS2 RNA transcript of $P$. malayense sp. nov. showing four common helices I to IV. When compared to its closest taxa, P. leve, two CBCs (open rectangles) and four HCBCs (shaded rectangles) were found. 
Table 3

Pairwise comparison of the ITS2 transcripts of Prorocentrum malayense and its closely related species showing the number of compensatory base changes (CBCs) and the respective ITS2 transcript length (bases).

\begin{tabular}{lllllll}
\hline Species & 1 & 2 & 3 & 4 & 5 & ITS2 length \\
\hline 1. P. malayense & 0 & & & & & 204 \\
2. P. leve & 2 & 0 & & & & 214 \\
3. $P$. cf. foraminosum & 1 & 1 & 0 & & & 236 \\
4. . sp. aff. foraminosum & 2 & 2 & 2 & 0 & & 192 \\
5. P. concavum & 2 & 2 & 3 & 1 & 0 & 200 \\
\end{tabular}

P. malayense differs from $P$. leve, which is transversely striated (Fig. $2 \mathrm{H}$ in David et al., 2014) or smooth without striation as reported in Faust et al. (2008). Recently, resting cyst of $P$. leve has been described (Mertens et al., 2017), unfortunately, no cyst was observed in P. malayense in this study, but this feature should be further investigated.

When compared to $P$. concavum, both are similarly broad in shape, with a V-shaped periflagellar area (Fig. 8; Faust, 1990). The two species, however, can be easily distinguished by the thecal surface ornamentation, where $P$. concavum is reticulate-foveated (Mohammad-Noor et al., 2007a; Chomérat et al., 2018). There is only one size class of thecal pores in $P$. malayense, $P$. concavum, on the contrary, has two different size classes of pores, some with the presence of a ring-like structure surrounding the pores (Hoppenrath et al., 2013). Marginal pores were present in $P$. malayense but absent in $P$. concavum.

Prorocentrum malayense is readily distinguished from $P$. foraminosum S.s. (Faust, 1993a,b), P. cf. foraminosum (Chomérat et al., 2018) and $P$. sp. aff. foraminosum sensu Chomérat et al. (2018) (Hoppenrath et al., 2013; Kameneva et al., 2015; Selina, 2017; Chomérat et al., 2018) based on the general cell shape and presence/absence of marginal pores (Table 2). Prorocentrum malayense was shorter $(37.6-44.7 \mu \mathrm{m}$ long, Table 2) as compared to P. foraminosum s.s. (46-66 $\mu \mathrm{m}$ long; Faust, 1993a). Cells of $P$. foraminosum s.l. are more elongated than $P$. malayense, the ratio of length to width (L:W) for P. malayense is 1.01-1.34 $(1.14 \pm 0.06, n=50)$, while $P$. foraminosum s.s. is $1.48-1.57$ (Faust, 1993a, b) and P. sp. aff. foraminosum is $1.30-1.87$ (Selina, 2017). In a peculiar case, $P$. foraminosum reported by Mohammad-Noor et al. (2007a) from Malaysian waters, despite its low representative sample size $(n=2)$, exhibits the range of cell dimension similar to that of $P$. malayense. The specimen by Mohammad-Noor et al. (2007a) is likely to be $P$. malayense, however, the description by Mohammad-Noor et al. (2007a) was made without the support of molecular data and the general morphological descriptions provided could not be used even to differentiate it from other closely related species of $P$. foraminosum, such as $P$. leve and $P$. concavum, we thus reserved to conclude that the two are the same species until further investigation. Other than cell shape, P. malayense possesses less thecal pores per plate (201-203) compared to that of $P$. foraminosum s.s. (270-350, Faust, 1993a, b). Prorocentrum malayense and $P$. cf. foraminosum share similar number of platelets (1a, 1b, 2, 3, 4, 5, 6, 7, and 8); however, platelet 2 and 3 of $P$. malayense are larger and broader when compared to those of $P$. cf. foraminosum (Chomérat et al., 2018), platelet 6 is longer than wide in $P$. malayense but is wider than long in $P$. cf. foraminosum (Figs. 1, 8; Chomérat et al., 2018). Notwithstanding some degrees of similarity in the periflagellar area, $P$. malayense and $P$. foraminosum s.l. are reliably differentiated by the presence of marginal pores, where marginal pores are absent in P. foraminosum s.s. (Faust, 1993a, b), P. cf. foraminosum (Chomérat et al., 2018) and $P$. sp. aff. foraminosum (Selina, 2017).

Molecular phylogenetic relationships of Prorocentrum in this study were inferred from two nuclear-encoded ribosomal RNA gene markers (LSU and ITS2) to address species delimitation. The LSU inferences generally agreed with the topologies depicted by Hoppenrath et al. (2013); David et al. (2014); Luo et al. (2017) and Mertens et al. (2017). The lineage of $P$. malayense was well resolved in our LSU tree, with the Malaysian and Chinese strains forming a strongly supported monophyletic clade (Fig. 6). Nucleotide heterogeneity based on uncorrected $p$-distance values also revealed high divergences between $P$. malayense and its closely related species ( $P$. leve, $P$. cf. foraminosum, $P$. sp. aff. foraminosum, and $P$. concavum) (see Supplementary Table S3).

Secondary structural information of ITS2 RNA transcript and the compensatory base changes (CBCs) has been used to study cryptic species of several harmful microalgae (e.g., Pseudo-nitzschia, Amato et al., 2007; Lim et al., 2012, 2013; Teng et al., 2014, 2015, 2016; Coolia, Leaw et al., 2010, 2016; Alexandrium ostenfeldii, Kremp et al., 2014; Ostreopsis rhodesae, Verma et al., 2016; P. koreanum, Han et al., 2016; Amphidinium, Karafas et al., 2017). Likewise, the phylogenetic trees reconstructed based on the orthologous sequence-structure alignment guided by the structural information of ITS2, has manifested high accuracy and robustness in the phylogenetic framework (e.g., Keller et al., 2009; Lim et al., 2013). The ITS2 tree in this study, even though depicted some differences in the taxon positions as compared to the LSU tree (Fig. 6), revealed a distinct lineage of $P$. malayense (see Fig. 7A). It is noteworthy that $P$. sp. aff. foraminosum in our ITS2 tree formed a separate reciprocally monophyletic lineage, demonstrating a high degree of genetic divergence between $P$. sp. aff. foraminosum and $P$. cf. foraminosum from the Caribbean. As stated in Chomérat et al. (2018), the two forms were likely representing two different species; the distinction of the two forms was also supported by morphological variations such as cell shape (see Fig. 8; as discussed in Chomérat et al., 2018).

This is the first study depicting the phylogenetic relationships of
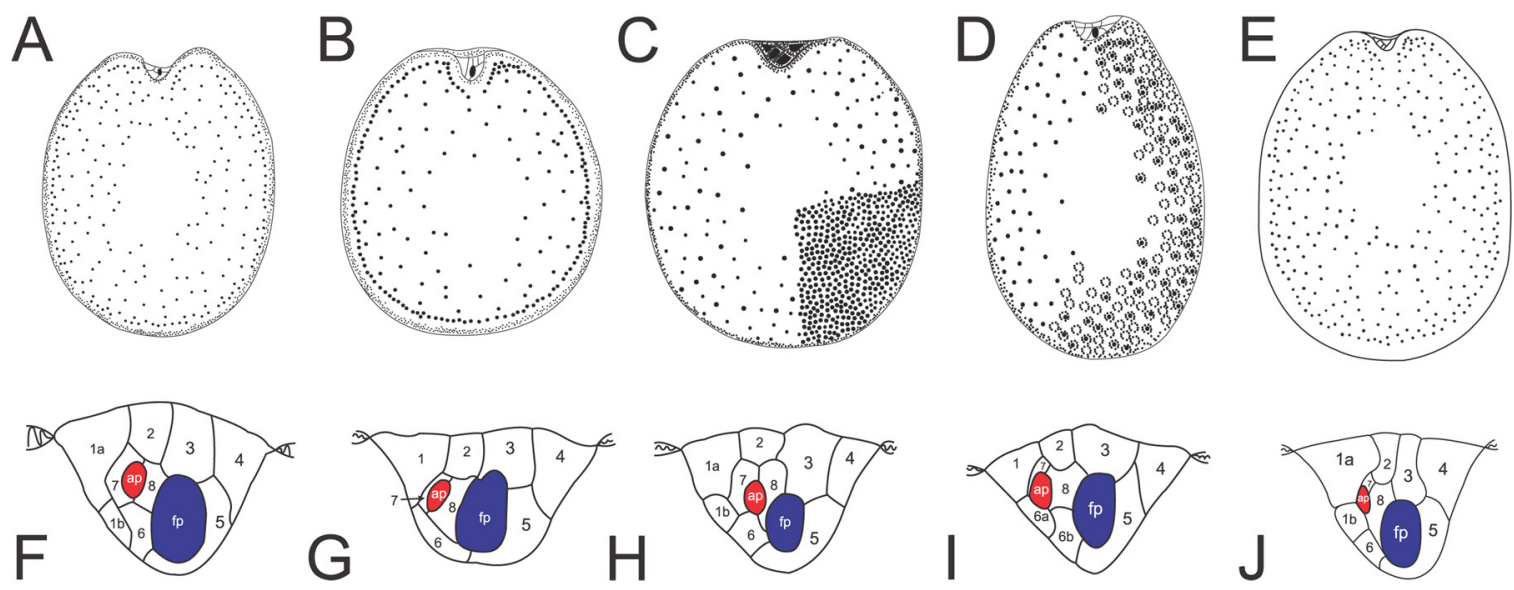

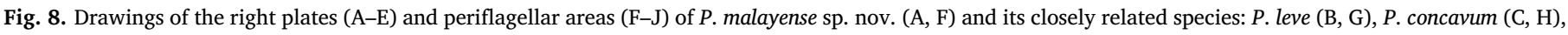
$P$. sp. aff. foraminosum (D, I) (adapted from Hoppenrath et al., 2013), and P. cf. foraminosum (E, J) (illustrated based on Chomérat et al., 2018). 
Prorocentrum based on ITS2 dataset with the sequence-structure information. The results of the $\mathrm{CBC}$ analysis revealed the presence of CBCs and HCBCs between P. malayense and P. leve (Fig. 7B), supporting the distinction of the two species. Similarly, CBCs were found between $P$. malayense and its closely related species: one $\mathrm{CBC}$ when compared with $P$. cf. foraminosum; two CBCs with $P$. sp. aff. foraminosum and $P$. concavum (Table 3).

\subsection{Taxonomic remarks of two toxic Prorocentrum species found in Rawa Island}

In this study, only $P$. lima and $P$. caipirignum have been confirmed to produce OA. Erection of $P$. caipirignum and its status in the $P$. lima complex was first clarified by Nascimento et al. (2017). Intriguingly, both $P$. lima and $P$. caipirignum in this study have been found in the same locality, allowing us to investigate and compare the two species morphologically and phylogenetically. Habitat preference likely varies between the two species, as the former was found attached to macroalgae and the latter was found in sediments (own observation). Several studies have documented the benthic distribution of Prorocentrum (Vila et al., 2001; Okolodkov et al., 2007, 2014; Yong et al., 2018). But as yet, very few studies focused on the ecological adaptation and habitat preference of benthic Prorocentrum at interspecific levels, this is not a topic to cover in this study but will be a subject to explore in the future.

Generally, morphological and molecular comparisons of $P$. lima and $P$. caipirignum are comparable to those previously described (Nagahama et al., 2011; Luo et al., 2014; Zhang et al., 2015; Nascimento et al., 2017; Chomérat et al., 2018). While previous morphological comparison has revealed similarity in the thecal pores of $P$. lima and $P$. caipirignum (Nascimento et al., 2017), we observed the distinct shape of thecal pores in the two species: kidney-shaped to elongated pores in $P$. caipirignum while small and round pores in P. lima. The marginal pores, although present in both species, the arrangement in $P$. lima is more compact compared to that of $P$. caipirignum. At the periflagellar area, the platelets differ in sizes for the two-species found in Malaysia, as a case in point: $P$. lima has larger platelet 2 ; platelet 3 of $P$. caipirignum is larger. Thus far, no comparison of distinct platelet sizes was made among species of the $P$. lima complex, this may be a useful feature in differentiating the species in the complex. The results of this study further supported the identity of $P$. caipirignum by comparing it with the closest species, $P$. lima, collected from the same water. Meanwhile, this study has expanded available taxonomic information by showing the consistency in some morphological traits (e.g., cell shapes as shown in Nascimento et al., 2017), adding also the information of the newly observed features of periflagellar area and pore shapes.

It is interesting to note that the molecular data indicated the grouping of Malaysian $P$. lima strain with other strains of $P$. lima morphotype 1 (cf. Zhang et al., 2015; Chomérat et al., 2018). In Nascimento et al. (2017), this clade has been ascribed to P. arenarium (Faust, 1994), However, based on the morphological dissimilarity between $P$. lima morphotype 1 (ovate-piriform shape) and $P$. arenarium (round shape) that observed in this and other studies (Grzebyk et al., 1998; Chomérat et al., 2018; this study), it is inconclusive to assign P. lima morphotype 1 clade as $P$. arenarium. Even though $P$. arenarium has been synonymized to $P$. lima (Nagahama et al., 2011), the phylogenetic position of this group could only be ascertained by obtaining more morphological and molecular data.

\subsection{Toxicity of Prorocentrum}

DSP-toxins production is likely an obligate trait in some benthic Prorocentrum species, particularly species in $P$. lima complex sensu Chomérat et al. (2018); there are numerous reports that showed consistent OA production in $P$. lima, $P$. caipirignum (previously as $P$. cf. maculosum) (Yasumoto et al., 1984; Hu et al., 2017; Luo et al., 2017) and P. hoffmannianum (Morton et al., 1994, 1998; Rodríguez et al.,
2018). The Malaysian strains of $P$. lima and $P$. caipirignum were also found to be capable of producing OA in this study. Cell quotas of the Malaysian strains of $P$. lima and $P$. caipirignum (1-3 $\mathrm{pg}^{\text {cell }}{ }^{-1}$ ) were within the range of cell quotas of other previously reported strains: e.g., the Chinese strains of $P$. lima and $P$. caipirignum $\left(0.55-10 \mathrm{pg} \mathrm{cell}^{-1}\right.$, Luo et al., 2017) and the Brazilian P. caipirignum strains (0.15-20 pg cell $^{-1}$, Nascimento et al., 2017). In contrast, OA production in $P$. mexicanum is likely strain-specific. Low OA levels have been reported in $P$. mexicanum strains from Malaysian Borneo (Caillaud et al., 2010), but the strains from the northern South China Sea were reported with an undetectable level of OA (Luo et al., 2017). Correspondingly, no detectable level of OA was observed in the Malaysian strain analyzed in this study.

While $P$. malayense was found non-toxic in this study, its closely related species were known to be DSP-toxins producers: OA was detected in P. concavum (Hu et al., 1992, 1993); and DTX-1 was detected in P. sp. aff. foraminosum from Japan (Kameneva et al., 2015). Although $\mathrm{OA}$ and DTX-2 were detected in $P$. leve from the Caribbean (per. comm.in Faust et al., 2008), no detectable toxins were found in the European strains (Mertens et al., 2017). The possibility that the species is toxic, however, cannot be ruled out as the ability to produce OA could be strain-specific (Paz et al., 2004).

Contamination of DSP toxins in filter-feeding seafood is an increasing issue worldwide, with the regulatory limit of $160 \mu \mathrm{g}$ OA equivalents per kilogram fresh weight set by European Union legislation. Nevertheless, the role of Prorocentrum in contributing to DSP events is unclear, particularly the benthic species. In fact, there are only a few reports that clearly associate DSP events with Prorocentrum as was the case in a DSP outbreak in Argentina, 1999 (Gayoso et al., 2002). This may be a methodological problem because routine phytoplankton monitoring programs sampled only the upper water column, but it may also be due to the fact that benthic microalgae, under normal conditions, are not ingested by filter feeding organisms. In exceptional cases, if high numbers of toxic Prorocentrum are suspended in the water column by storms or other mechanical disruptions of the epifloral ecosystem, high numbers of Prorocentrum may become available as food for filter-feeders. In the case of $P$. lima and P. caipirignum, at least 50 million ingested cells would be necessary to reach the regulatory limit of $160 \mu \mathrm{g} \mathrm{OA}$ eq. $\mathrm{kg}^{-1}$ shellfish. Even though this scenario is not likely in many cases, Prorocentrum DSP toxicity in many other cases may very well superimpose upon DSP toxicity primarily caused by pelagic Dinophysis abundance. To date, the synergetic effects between the simultaneous abundance of Dinophysis and Prorocentrum on DSP toxin accumulation in bivalves have not been addressed and this highlights the need for further investigation on this topic.

\section{Acknowledgments}

We acknowledged the funding of MESTECC International Cooperation Fund [UM0042224/CF001-2018] and the Malaysian Ministry of Education HiCoE [IOES-2014C]. This work was partially funded by China-ASEAN Maritime Cooperation Fund; Emergency Management Program, National Natural Science Foundation of China [41641051 and HX150702]; Shenzhen Key Laboratory Program, Science, Technology and Innovation Commission of Shenzhen Municipality [ZDSYSY20140509155229806]; and HelmholtzGemeinschaft Deutscher Forschungszentren through the research program "Polar regions and Coasts in the changing Earth System" (PACES II) of the Alfred Wegener Institut-Helmholtz Zentrum für Polar- und Meeresforschung. We are grateful to Dr. John Hodgkiss (City University of Hong Kong) for assistance with the English on the draft manuscript. This work forms part of the MSc project of ZF Lim.[CG]

\section{Appendix A. Supplementary data}

Supplementary material related to this article can be found, in the online version, at doi:https://doi.org/10.1016/j.hal.2019.01.007. 


\section{References}

Aligizaki, K., Nikolaidis, G., Katikou, P., Baxevanis, A.D., Abatzopoulos, T.J., 2009. Potentially toxic epiphytic Prorocentrum (Dinophyceae) species in Greek coastal waters. Harmful Algae 8, 299-311.

Amato, A., Kooistra, W.H., Ghiron, J.H.L., Mann, D.G., Pröschold, T., Montresor, M., 2007. Reproductive isolation among sympatric cryptic species in marine diatoms. Protist 158, 193-207.

Caillaud, A., de la Iglesia, P., Campàs, M., Elandaloussi, L., Fernández, M., MohammadNoor, N., Andree, K., Diogène, J., 2010. Evidence of okadaic acid production in a cultured strain of the marine dinoflagellate Prorocentrum rhathymum from Malaysia. Toxicon 55, 633-637.

Chomérat, N., Sellos, D.Y., Zentz, F., Nézan, E., 2010. Morphology and molecular phylogeny of Prorocentrum consutum sp. nov. (Dinophyceae), a new benthic dinoflagellate from South Brittany (northwestern France). J. Phycol. 46, 183-194.

Chomérat, N., Bilien, G., Zentz, F., 2018. A taxonomical study of benthic Prorocentrum species (Prorocentrales, Dinophyceae) from Anse Dufour (Martinique Island, eastern Caribbean Sea). Mar. Biodiver. https://doi.org/10.1007/s12526-018-0913-6.

Darriba, D., Taboada, G.L., Doallo, R., Posada, D., 2012. jModelTest 2: more models, new heuristics and parallel computing. Nat. Methods 9, 772.

Darty, K., Denise, A., Ponty, Y., 2009. VARNA: interactive drawing and editing of the RNA secondary structure. Bioinformatics 25, 1974-1975.

David, H., Laza-Martínez, A., García-Etxebarria, K., Riobó, P., Orive, E., 2014. Characterization of Prorocentrum elegans and Prorocentrum levis (Dinophyceae) from the southeastern Bay of Biscay by morphology and molecular phylogeny. J. Phycol. 50, 718-726.

Edgar, R.C., 2004. MUSCLE: multiple sequence alignment with high accuracy and high throughput. Nucleic Acids Res. 32, 1792-1797.

Faust, M.A., 1990. Morphologic details of six benthic species of Prorocentrum (pyrrophyta) from a mangrove island, Twin cays, Belize, including two new species. J. Phycol. 26, 548-558.

Faust, M., 1993a. Three new benthic species of Prorocentrum (Dinophyceae) from Twin Cays, Belize: P. Maculosum sp. nov., P. Foraminosum sp. nov. And P. Formosum sp. nov. Phycologia 32, 410-418.

Faust, M.A., 1993b. Three new benthic species of Prorocentrum (Dinophyceae) from Twin Cays, Belize: P. Maculosum sp. nov., P. Foraminosum sp. nov. and P. Formosum sp. nov. Phycologia 32, 410-418.

Faust, M.A., 1994. Three new benthic species of Prorocentrum (Dinophyceae) from Carrie Bow Cay, Belize: P. sabulosum sp. nov., P. sculptile sp. nov., and P. arenarium sp. nov. J. Phycol. 30, 755-763.

Faust, M.A., Gulledge, R.A., 2002. Identifying Harmful Marine Dinoflagellates, vol 42 Smithsonian Institution, Contributions from the United States National Herbarium, pp. 1-144.

Faust, M.A., Vandersea, M.W., Kibler, S.R., Tester, P.A., Litaker, R.W., 2008. Prorocentrum levis, a new benthic species (Dinophyceae) from a mangrove island, Twin Cays, Belize1. J. Phycol. 44, 232-240.

Fukuyo, 1981. Taxonomical study on benthic dinoflagellates collected in coral reefs. Bull. Japan. Soc. Sci. Fish. 47, 967-978.

Gayoso, A.M., Dover, S., Morton, S., Busman, M., Moeller, P., Fulco, V.K., Maranda, L. 2002. Diarrhetic shellfish poisoning associated with Prorocentrum lima (Dinophyceae) in Patagonian gulfs (Argentina). J. Shellfish Res. 21, 461-463.

Guiry, M., Guiry, G., 2018. AlgaeBase. World-wide Electronic Publication. National University of Ireland, Galway Accessed on 1/10/2018). http://www.algaebase.org/ search/species/.

Han, M.-S., Wang, P., Kim, J.H., Cho, S.-Y., Park, B.S., Kim, J.-H., Katano, T., Kim, B.-H., 2016. Morphological and molecular phylogenetic position of Prorocentrum micans sensu stricto and description of Prorocentrum koreanum sp. nov. from southern coastal waters in Korea and Japan. Protist 167, 32-50.

Henrichs, D.W., Scott, P.S., Steidinger, K.A., Errera, R.M., Abraham, A., Campbell, L., 2013. Morphology and phylogeny of Prorocentrum texanum sp. nov. (Dinophyceae): a new toxic dinoflagellate from the Gulf of Mexico coastal waters exhibiting two distinct morphologies. J. Phycol. 49, 143-155.

Herrera-Sepúlveda, A., Medlin, L.K., Murugan, G., Sierra-Beltrán, A.P., Cruz-Villacorta, A.A., Hernández-Saavedra, N.Y., 2015. Are Prorocentrum hoffmannianum and Prorocentrum belizeanum (Dinophyceae, Prorocentrales), the same species? An integration of morphological and molecular data. J. Phycol. 51, 173-188.

Hofacker, I.L., 2003. Vienna RNA secondary structure server. Nucleic Acids Res. 31, 3429-3431.

Holmes, M.J., Lee, F.C., Khoo, H.W., Teo, S.L.M., 2001. Production of 7-deoxy-okadaic acid by a new Caledonian strain of Prorocentrum lima (Dinophyceae). J. Phycol. 37, 280-288.

Hoppenrath, M., Chomérat, N., Horiguchi, T., Schweikert, M., Nagahama, Y., Murray, S., 2013. Taxonomy and phylogeny of the benthic Prorocentrum species (Dinophyceae) A proposal and review. Harmful Algae 27, 1-28.

Hoppenrath, M., Murray, S.A., Chomérat, N., Horiguchi, T., 2014. Marine benthic dinoflagellates-unveiling their worldwide biodiversity. Kleine Senckenberg-Reihe 134-152.

Hu, T., Marr, J., de Freitas, A.S., Quilliam, M.A., Walter, J.A., Wright, J.L., Pleasance, S., 1992. New diol esters isolated from cultures of the dinoflagellates Prorocentrum lima and Prorocentrum concavum. J. Nat. Prod. 55, 1631-1637.

Hu, T., Defreitas, A., Doyle, J., Jackson, D., Marr, J., Nixon, E., Pleasance, S., 1993. New DSP toxin derivatives isolated from toxic mussels and the dinoflagellates, Prorocentrum lima and Prorocentrum concavum. Dev. Mar. Biol. 1993.

Hu, T., LeBlanc, P., Burton, I.W., Walter, J.A., McCarron, P., Melanson, J.E., Strangman, W.K., Wright, J.L., 2017. Sulfated diesters of okadaic acid and DTX-1: self-protective precursors of diarrhetic shellfish poisoning (DSP) toxins. Harmful Algae 63, 85-93.

Kameneva, P.A., Efimova, K.V., Rybin, V.G., Orlova, T.Y., 2015. Detection of dinophysistoxin-1 in clonal culture of marine dinoflagellate Prorocentrum foraminosum (Faust MA, 1993) from the Sea of Japan. Toxins 7, 3947-3959.

Karafas, S., Teng, S.T., Leaw, C.P., Alves-de-Souza, C., 2017. An evaluation of the genus Amphidinium (Dinophyceae) combining evidence from morphology, phylogenetics, and toxin production, with the introduction of six novel species. Harmful Algae 68, $128-151$.

Keller, A., Schleicher, T., Schultz, J., Müller, T., Dandekar, T., Wolf, M., 2009. 5.8S-28S rRNA interaction and HMM-based ITS2 annotation. Gene 430, 50-57.

Keller, A., Förster, F., Müller, T., Dandekar, T., Schultz, J., Wolf, M., 2010. Including RNA secondary structures improves accuracy and robustness in reconstruction of phylogenetic trees. Biol. Direct 5, 4.

Kokinos, J.P., Anderson, D.M., 1995. Morphological development of resting cysts in cultures of the marine dinoflagellate Lingulodinium polyedrum $(=$ L. machaerophorum). Palynology 19, 143-166.

Kremp, A., Tahvanainen, P., Litaker, W., Krock, B., Suikkanen, S., Leaw, C.P., Tomas, C., 2014. Phylogenetic relationships, morphological variation, and toxin patterns in the Alexandrium ostenfeldii (Dinophyceae) complex: implications for species boundaries and identities. J. Phycol. 50, 81-100.

Krock, B., Tillmann, U., John, U., Cembella, A., 2008. LC-MS-MS aboard ship: tandem mass spectrometry in the search for phycotoxins and novel toxigenic plankton from the North Sea. Anal. Bioanal. Chem. 392, 797-803.

Leaw, C.P., Teen, L.P., Ahmad, A., Usup, G., 2001. Genetic diversity of Ostreopsis ovata (Dinophyceae) from Malaysia. Mar. Biotechnol. 3, 246-255.

Leaw, C.P., Lim, P.T., Cheng, K.W., Ng, B.K., Usup, G., 2010. Morphology and molecular characterization of a new species of thecate benthic dinoflagellate, Coolia malayensis sp. nov. (Dinophyceae). J. Phycol. 46, 162-171.

Leaw, C.P., Tan, T.H., Lim, H.C., 2016. New scenario for speciation in the benthic dinoflagellate genus Coolia (Dinophyceae). Harmful Algae 55, 137-149.

Lim, H.C., Leaw, C.P., Su, S.N.P., Teng, S.T., Usup, G., Mohammad-Noor, N., Lundholm, N., Kotaki, Y., Lim, P.T., 2012. Morphology and molecular characterization of Pseudo-nitzschia (Bacillariophyceae) from Malaysian Borneo, including the new species Pseudo-nitzschia circumpora sp. nov. J. Phycol. 48 (5), 1232-1247.

Lim, H.C., Teng, S.T., Leaw, C.P., Lim, P.T., 2013. Three novel species in the Pseudonitzschia pseudodelicatissima complex: P. Batesiana sp. nov., P. Lundholmiae sp. nov., and P. Fukuyoi sp. nov. (Bacillariophyceae) from the Strait of Malacca, Malaysia. J. Phycol. 49, 902-916.

Luo, Z., Zhang, H., Krock, B., Lu, S., Yang, W., Gu, H., 2017. Morphology, molecular phylogeny and okadaic acid production of epibenthic Prorocentrum (Dinophyceae) species from the northern South China Sea. Algal Res. 22, 14-30.

Mertens, K.N., Gu, H., Pospelova, V., Chomérat, N., Nézan, E., Gurdebeke, P.R., Bogus, K., Vrielinck, H., Rumebe, M., Meteigner, C., 2017. First record of resting cysts of the benthic dinoflagellate Prorocentrum leve in a natural reservoir in Gujan-Mestras, Gironde, France. J. Phycol. 53, 1193-1205.

Mohammad-Noor, N., Daugbjerg, N., Moestrup, O., Anton, A., 2007a. Marine epibenthic dinoflagellates from Malaysia - A study of live cultures and preserved samples based on light and scanning electron microscopy. Nord. J. Bot. 24, 629-690.

Mohammad-Noor, N., Moestrup, Ø., Daugbjerg, N., 2007b. Light, electron microscopy and DNA sequences of the dinoflagellate Prorocentrum concavum (syn. P. arabianum) with special emphasis on the periflagellar area. Phycologia 46, 549-564.

Morton, S.L., Bomber, J.W., Tindall, P.M., 1994. Environmental effects on the production of okadaic acid from Prorocentrum hoffmannianum Faust. Temperature, light, and salinity. J. Exp. Mar. Bio. Ecol. 178, 67-77.

Morton, S.L., Moeller, P.D., Young, K., Lanoue, B., 1998. Okadaic acid production from the marine dinoflagellate Prorocentrum belizeanum Faust isolated from the Belizean coral reef ecosystem. Toxicon 36, 201-206.

Murakami, Y., Oshima, Y., Yasumoto, T., 1982. Identification of okadaic acid as a toxic component of a marine dinoflagellate Prorocentrum lima. Bull. Japan. Soc. Sci. Fish. 48, 69-72.

Murray, S., Nagahama, Y., Fukuyo, Y., 2007. Phylogenetic study of benthic, spine-bearing prorocentroids, including Prorocentrum fukuyoi sp. nov. Phycol. Res. 55, 91-102.

Nagahama, Y., Murray, S., Tomaru, A., Fukuyo, Y., 2011. Species boundaries in the toxic dinoflagellate Prorocentrum lima (Dinophyceae, Prorocentrales), based on morphological and phylogenetic characters. J. Phycol. 47, 178-189.

Nascimento, S.M., Salgueiro, F., Menezes, M., de Andréa Oliveira, F., Magalhães, V.C.P. De Paula, J.C., Morris, S., 2016. Prorocentrum lima from the South Atlantic: morphological, molecular and toxicological characterization. Harmful Algae 57, 39-48.

Nascimento, S.M., Mendes, M.C.Q., Menezes, M., Rodríguez, F., Alves-de-Souza, C., Branco, S., Riobó, P., Franco, J., Nunes, J.M.C., Huk, M., Morris, S., 2017. Morphology and phylogeny of Prorocentrum caipirignum sp. nov. (Dinophyceae), a new tropical toxic benthic dinoflagellate. Harmful Algae 70, 73-89.

Okolodkov, Y.B., Campos-Bautista, G., Gárate-Lizárraga, I., González-González, J.A.G., Hoppenrath, M., Arenas, V., 2007. Seasonal changes of benthic and epiphytic dinoflagellates in the Veracruz reef zone, Gulf of Mexico. Aquat. Microb. Ecol. 47, 223-237.

Okolodkov, Y.B., Merino-Virgilio, F., del, C., Aké-Castillo, J.A., Aguilar-Trujillo, A.C., Espinosa-Matías, S., Herrera-Silveira, J.A., 2014. Seasonal changes in epiphytic dinoflagellate assemblages near the northern coast of the Yucatan Peninsula, Gulf of Mexico. Acta Bot. Mex. 107, 121-151.

Paz, B., Riobó, P., Fernández, M.L., Fraga, S., Franco, J.M., 2004. Production and release of yessotoxins by the dinoflagellates Protoceratium reticulatum and Lingulodinium polyedrum in culture. Toxicon 44, 251-258.

Posada, D., 2008. jModelTest: phylogenetic model averaging. Mol. Biol. Evol. 25, 1253-1256.

Reuter, J.S., Mathews, D.H., 2010. RNAstructure: software for RNA secondary structure 
prediction and analysis. BMC Bioinf. 11, 129.

Rodríguez, F., Riobó, P., Crespín, G.D., Daranas, A.H., de Vera, C.R., Norte, M., Fernández, J.J., Fraga, S., 2018. The toxic benthic dinoflagellate Prorocentrum maculosum Faust is a synonym of Prorocentrum hoffmannianum Faust. Harmful Algae 78, 1-8.

Ronquist, F., Teslenko, M., Van Der Mark, P., Ayres, D.L., Darling, A., Höhna, S., Larget, B., Liu, L., Suchard, M.A., Huelsenbeck, J.P., 2012. MrBayes 3.2: efficient Bayesian phylogenetic inference and model choice across a large model space. Syst. Biol. 61 539-542.

Schliep, K.P., 2010. Phangorn: Phylogenetic Analysis in R. Bioinformatics, volume 27. pp. 592-593.

Scholin, C.A., Herzog, M., Sogin, M., Anderson, D.M., 1994. Identification of group-and strain-specific genetic markers for globally distributed Alexandrium (Dinophyceae). II. Sequence analysis of a fragment of the LSU rRNA gene. J. Phycol. 30, 999-1011.

Schultz, J., Wolf, M., 2009. ITS2 sequence-structure analysis in phylogenetics: a how-to manual for molecular systematics. Mol. Biol. Evol. 52, 520-523.

Seibel, P.N., Müller, T., Dandekar, T., Schultz, J., Wolf, M., 2006. 4SALE-a tool for synchronous RNA sequence and secondary structure alignment and editing. BMC Bioinf. 7, 498.

Seibel, P.N., Müller, T., Dandekar, T., Wolf, M., 2008. Synchronous visual analysis and editing of RNA sequence and secondary structure alignments using 4SALE. BMC Res. Notes 1, 91.

Selina, M., 2017. The morphology and seasonal dynamics of the potentially toxic microalga Prorocentrum foraminosum Faust 1993 (Dinophyta) in Peter the Great Bay, the Sea of Japan. Russ. J. Mar. Biol. 43, 196-201.

Swofford, D., 2000. PAUP And Other Methods. Phylogenetic Analysis Using Parsimony. Sinauer Associates, Sunderland, MA.

Tamura, K., Stecher, G., Peterson, D., Filipski, A., Kumar, S., 2013. MEGA6: molecular evolutionary genetics analysis version 6.0. Mol. Biol. Evol. 30, 2725-2729.

Teng, S.T., Lim, H.C., Lim, P.T., Dao, V.H., Bates, S.S., Leaw, C.P., 2014. Pseudo-nitzschia kodamae sp. nov. (Bacillariophyceae), a toxigenic species from the Strait of Malacca,
Malaysia. Harmful Algae 34, 17-28.

Teng, S.T., Lim, P.T., Lim, H.C., Rivera-Vilarelle, M., Quijano-Scheggia, S., Takata, Y., Quilliam, M.A., Wolf, M., Bates, S.S., Leaw, C.P., 2015. A non-toxigenic but morphologically and phylogenetically distinct new species ofPseudo-nitzschia, P. sabit sp. nov. (Bacillariophyceae). J. Phycol. 51, 706-725.

Teng, S.T., Tan, S.N., Lim, H.C., Dao, V.H., Bates, S.S., Leaw, C.P., 2016. High diversity of Pseudo-nitzschia along the northern coast of Sarawak (Malaysian Borneo), with descriptions of $P$. bipertita sp. nov. and P. limii sp. nov. (Bacillariophyceae). J. Phycol. 52, 973-989.

Verma, A., Hoppenrath, M., Dorantes-Aranda, J.J., Harwood, D.T., Murray, S.A., 2016. Molecular and phylogenetic characterization of Ostreopsis (Dinophyceae) and the description of a new species, Ostreopsis rhodesae sp. nov., from a subtropical Australian lagoon. Harmful Algae 60, 116-130.

Vila, M., Garcés, E., Masó, M., 2001. Potentially toxic epiphytic dinoflagellate assemblages on macroalgae in the NW Mediterranean. Aquat. Microb. Ecol. 26, 51-60.

Wolf, M., Achtziger, M., Schultz, J., Dandekar, T., Müller, T., 2005. Homology modeling revealed more than 20,000 rRNA internal transcribed spacer 2 (ITS2) secondary structures. RNA 11, 1616-1623.

Wolf, M., Koetschan, C., Müller, T., 2014. ITS2, 18S, 16S or any other RNA - simply aligning sequences and their individual secondary structures simultaneously by an automatic approach. Gene 546, 145-149.

Yasumoto, T., Murata, M., Oshima, Y., Matsumoto, G.K., Clardy, J., 1984. Diarrhetic Shellfish Poisoning. ACS Publications., pp. 207-214.

Yong, H.L., Mustapa, N.I., Lee, L.K., Lim, Z.F., Tan, T.H., Usup, G., Gu, H., Litaker, R.W., Tester, P.A., Lim, P.T., Leaw, C.P., 2018. Habitat complexity affects benthic harmful dinoflagellate assemblages in the fringing reef of Rawa Island, Malaysia. Harmful Algae 78, 56-68.

Zhang, H., Li, Y., Cen, J., Wang, H., Cui, L., Dong, Y., Lu, S., 2015. Morphotypes of Prorocentrum lima (Dinophyceae) from Hainan island, South China Sea: morphological and molecular characterization. Phycologia 54, 503-516. 